\title{
Does violent conflict affect the labor supply of farm households? The Nigerian experience
}

\author{
John Chiwuzulum Odozi ${ }^{1}$ and Ruth Uwaifo Oyelere ${ }^{2,3,4 *}$ (D) \\ ${ }^{1}$ Department of Agricultural Economics and Extension, Ajayi Crowther University, Oyo, Oyo State, \\ Nigeria, ${ }^{2}$ Department of Economics and Business Management, Agnes Scott College, Decatur, GA, USA, \\ ${ }^{3}$ Institute for the Study of Labor (IZA), Bonn, Germany and ${ }^{4}$ Global Labor Organization (GLO) \\ ${ }^{*}$ Corresponding author. Email: ruwaifo@agnesscott.edu
}

(Received 14 November 2020; revised 17 July 2021; accepted 19 July 2021; first published online 17 August 2021)

\begin{abstract}
Nigeria has experienced bouts of violent conflict in different regions since its independence leading to significant loss of life. In this article, we explore the average effect of exposure to violent conflict generally on labor supply in agriculture. Using a nationally representative panel dataset for Nigeria from 2010 to 2015, in combination with armed conflict data, we estimate the average effect of exposure to violent conflict on a household's farm labor supply. Our findings suggest that on average, exposure to violent conflict significantly reduces total family labor supply hours in agriculture. We also find that the decline in family labor supply is driven by a significant decline in the household head's total number of hours on the farm.
\end{abstract}

Keywords: Boko Haram; ethnoreligious conflict; farm households; farmer-herdsmen conflict; labor supply; Nigeria; Niger-Delta conflict; violent conflict

JEL: Q10; Q12; O1; D74

\section{Introduction}

The agricultural sector holds a significant role in developing countries and Nigeria is no exception. According to data from the World Bank, agriculture is the largest employer of labor in Nigeria. Employment in agriculture (percent of total employment) in Nigeria was reported at 36.38 percent in 2019. The sector is also the largest incomegenerating activity, with contributions to the gross domestic product (GDP) of about 24-30 percent. Unfortunately, the agricultural sector is particularly vulnerable to violent conflict. ${ }^{1}$ In particular, through killings, injuries, maiming of individuals, threats, fear, migration, and displacement, violent conflict affects directly the labor supply and demand of agricultural households.

Over the last few years, studies examining the impact of violent conflict on agricultural outcomes using micro-level data have increased. Many of these articles provide

\footnotetext{
${ }^{1}$ See Adelaja and George (2019a, 2019b) for reasons behind this vulnerability.

(c) The Author(s), 2021. Published by Cambridge University Press on behalf of the Northeastern Agricultural and Resource Economics Association. This is an Open Access article, distributed under the terms of the Creative Commons Attribution licence (http://creativecommons.org/licenses/by/4.0/), which permits unrestricted re-use, distribution, and reproduction in any medium, provided the original work is properly cited.
} 
evidence of the adverse effect of conflict on agricultural production through different pathways, including reduced access to credit and decline in labor supply (see Verpoorten 2009; Blattman and Miguel 2010; Verwimp, Justino, and Brück 2018; Brück, d'Errico, and Pietrelli 2019). With respect to Nigeria, research on the impact of conflict on agriculture-related outcomes has increased. However, there is still room for more knowledge on the impact of conflict in Nigeria on certain agricultural outcomes. ${ }^{2}$ In particular, while Adelaja and George (2019a) examined the effects of Boko Haram insurgency on output and input demand including the demand for hired labor and supply of family labor, the impact of conflict on the labor supply of a household head, spouse, and children was not examined separately. Given the possibility of a heterogeneous impact of conflict on labor supply, a more robust investigation is useful and is one of the motivations for our research.

The main motivation for our research is the current gap in the conflict literature on Nigeria. In particular, the recent past literature on the conflict in Nigeria focused primarily on the impact of the Boko Haram insurgency on different health, economic, and labor market outcomes. This focus on Boko Haram political violence could be limiting in perspective, given Nigeria's past history of violent conflict in different locations, at different times, driven by different actors and perpetrators. The reality is that armed conflict has plagued Nigeria long before the onset of the Boko Haram crises. Currently, in Nigeria, violence erupting from the farmer-herdsmen conflict, bandit attacks, and Fulani militia has increased precipitously and has led to a significant number of fatalities. Therefore, a research focus on Boko Haram cannot provide perspective for the current growing crises as the states, local government, towns, and villages that have had direct exposure to this growing violent conflict are different from the communities that have been significantly affected by Boko Haram attacks and abductions. The changes in violence hotspots in Nigeria over time are evidence of the proliferation and widespread nature of conflict in Nigeria. Moreover, the changes that have occurred in the profile of perpetrators and in location are a reminder of the heterogeneity in conflict exposure across communities. Given that violent conflict in Nigeria goes beyond Boko Haram or the farmer-herdsman current conflict, and with recent results on Nigeria by Odozi and Oyelere (2019) suggesting negative welfare effects of violent conflict in general, then, examining the effect of violent conflict generally on labor supply, one of the potential channels that could explain their finding, is a fruitful exercise that promises to valuable insights. This is the goal of our article.

In this article, we focus on two related questions as we attempt to bridge the gap in the existing literature on the effect of conflict on farm labor supply. First, does recent exposure to violent conflict affect total family labor hours and is there heterogeneity in effect on the number of hours worked by the household head, spouse, children, and relatives? Second, does long-term accumulated exposure to conflict (direct or indirect) affect total family labor hours supplied and is there heterogeneity in effect on the number of hours worked by the household head, spouse, children, and relatives? For both questions, we focus on small holder farm households. ${ }^{3}$ We attempt to answer these questions using household survey panel data for Nigeria in combination with data from The Armed Conflict Location \& Event Data (ACLED) by Raleigh et al. (2010).

To examine both the short-term and long-term effects of conflict exposure on labor supply, we construct two measures of conflict exposure based on conflict-related

\footnotetext{
${ }^{2}$ See the literature review section for a detailed summary of past literature on Nigeria.

${ }^{3}$ We define farm households as agricultural households with at least one plot.
} 
fatalities. We refer to our first measure as recent exposure to conflict and the second measure as long-term accumulated exposure to conflict. ${ }^{4}$ To estimate the effect of conflict on farm labor supply, we initially use a Heckman selection model that can attenuate self-selection bias. However, given the limitations of the Heckman model, we consider it simply as our baseline model. ${ }^{5}$ To derive consistent estimates, we subsequently use a fixed effects approach exploiting the panel nature of our data. The fixed effects approach is our preferred method for our analysis because this approach uses within household variation over time, thereby attenuating potential biases in estimated effects. In particular, it eliminates biases linked with unobserved time-invariant differences across households that affect labor supply and are also correlated to conflict exposure. $^{6}$

Our results provide evidence of the significant negative effect of both recent exposure to conflict and accumulated exposure to conflict on total family farm labor supply. When we consider the different sources of farm labor, we find that the significant effect of conflict is driven by a decline in the labor supply of household heads. We do not find any significant effect on the farm labor of children or spouse. Our results using the Heckman selection model corroborate our fixed effect results.

Our article contributes to the literature by providing the first analysis in Nigeria on the overall average effect of exposure to violent conflict between 1999 and 2015 on the farm labor supply of agricultural households. While we are not the first to examine the effect of specific conflicts in Nigeria on agricultural outcomes such as productivity or the number of hours worked, our article provides a broad perspective that is value adding and fills a gap in the literature. Adelaja and George (2019a) focusing solely on the effects of Boko Haram did not find any impact of that particular conflict on total family labor supply. In contrast, our results suggest that violent conflict in Nigeria on average negatively affects total family labor supply, and within households, the farm labor supply of household heads is significantly reduced.

Another contribution of our article is that our results suggest significant lingering negative effects of armed conflict on labor supply, which has relevant policy implications. As mentioned above, the agricultural sector in Nigeria is a major employer of labor and contributes significantly to the GDP. Farm households are both users and suppliers of labor for upstream primary agricultural production activities, whether planting, rearing, weeding, nurturing, and harvesting. The link of farm household activities with downstream agricultural activities raises the policy importance of farm labor supply as a channel of poverty reduction and national food security. Hence, shocks that negatively affect labor supply have downstream effects that ultimately could affect welfare negatively, leading to increases in poverty incidence and severity. Odozi and Oyelere (2019) provide evidence that exposure to violent conflict significantly reduces income and increases incidence, depth, and severity of poverty in Nigeria. However, the pathways through which conflict decreases income or increases poverty have not been investigated. The results in our article also contribute to the literature by providing

\footnotetext{
${ }^{4}$ We explain in detail how we construct these measures in other sections of the article.

${ }^{5}$ It is challenging to come up with an excluded variable that does not directly affect the outcome and affects the selection.

${ }^{6}$ In earlier versions of the article, we also explored the effect of conflict on labor force participation using multiple estimation strategies, including a fixed effect logit model, a linear probability fixed effect model, and a probit model with correlated random effects. In all specifications, we did not find a significant effect of conflict exposure on participation in the labor force.
} 
evidence of one possible pathway through which conflict could have increased poverty. In particular, violent conflict reduces the hours of labor supplied by farm households. This reduction in labor supply decreases production and earnings and increases the vulnerability of farm households to falling under the poverty line or sinking deeper into poverty.

The rest of our article proceeds as follows. In the next section, we provide a background of conflict in Nigeria. In the section estimation results, we review the past literature. Conceptual framework: labor supply and conflict is a synopsis of our conceptual framework. Empirical strategy focuses on our empirical strategy for answering our questions of interest. In data and descriptive analysis, we present our data and descriptive analysis. In results, we present our results. We conclude in the last section.

\section{Background: conflict in Nigeria}

Violent conflict is a significant part of Nigeria's history and is still an ongoing reality for many Nigerians today. While the ongoing global COVID-19 pandemic has claimed many lives and is dominating government and different stakeholder conversations, violent conflict that has been escalating in Nigeria has not gotten as much attention. ${ }^{7}$ The challenge that lies with this inadequate attention is the neglect of the significant impact that violent conflict is having on groups, particularly farming communities. It is worth noting that between 2020 and 2021, violent conflict has led to higher fatalities than even COVID-19-related deaths. ${ }^{8}$

Nigeria's episodes of violent conflict are not just a recent occurrence of the twentyfirst century. Violent conflict in Nigeria is somewhat eclectic and may be defined as low intensity. What appears to be changing with respect to conflict in Nigeria is the players or perpetrators and the intensity of fatalities and frequency of events that have escalated over the last 15 years. Odozi and Oyelere (2019) provide a detailed summary of the history and nature of conflict in Nigeria. They note that in the 1960s the violent conflict events in Nigeria were linked with political challenges instigated by state creations (Tiv Riots), political unrest, military coups, and attempts of a region of Nigeria to secede. The Biafran Civil War of 1967-1970 was the end product of some of the crises that characterized this decade. While political conflict as a source of violence in Nigeria continues to persist, other dimensions of conflict have emerged that have led to significant fatalities and new hotspots. In the 1970s, 1980s, and 1990s violent conflict in Nigeria was also common place. The conflicts were heterogeneous with respect to location and perpetrator. Some known examples are the Bakolori Massacre, Odi massacre, and the 1980 Kano riot. One reoccurring type of conflict is religious conflict, usually between Christians and Muslims. Religious and ethnoreligious conflict events became quite a common place in Nigeria in the 1980s and 1990s especially in the northern part of the country.

Another major source of conflict since the early 90 s is the Niger Delta conflict. The conflict in this region has been driven by the struggle among local communities, multinational oil companies, and the Nigerian state for control over the resource-rich territory and oil revenues. The Movement for the Emancipation of the Niger Delta

\footnotetext{
${ }^{7}$ As of June 3rd 2021, official COVID-19-related deaths in Nigeria were 2,099-source https://www. worldometers.info/coronavirus/.com

${ }^{8}$ Data from The Nigeria Security Tracker (NST) show at least 3,801 conflict deaths between 2020 and June 2021.
} 
(MEND) emerged and had became violent since 2006 (Courson 2009). Their violent activities were characterized by oil worker abductions, attacks of government forces, and oil installation sabotages.

Since 2000, violent conflict in Nigeria has increased precipitously. According to estimates from Nigeria's National Commission for Refugees between 2003 and 2008, there were an estimated 3.2 million Internal Displaced Persons (IDPs) in Nigeria resulting from conflict. Within communal conflict, there has also been a significant increase in both ethnoreligious and farmer-herder conflict, but farmer-herder conflict increases are more common. Recent data suggest that between 2010 and 2019, nearly 19,000 people had died as a result of conflict of this type. ${ }^{9}$ The last five to six years have been characterized by a significant increase in massacres by herdsmen, and while most of these attacks were localized within Benue and Plateau state, there has been a proliferation of killings linked with herdsmen in multiple locations across Nigeria. ${ }^{10}$ In fact, the farmerherder conflict has evolved into armed banditry involving cattle rustling, destruction or theft of farm crops, kidnaping, and armed robbery. As noted in Olaniyi (2015), unlike the sedentary Fulani, the Bororo Fulani herders are considered very aggressive and always fully armed with AK-47 s, charms, and cutlasses and attack farmers and communities with lethal weapons.

Another major kind of perpetrator of conflict in Nigeria emerged in 2009 and has gotten the most attention internationally. Since 2009, the rise of Boko Haram has added to the already significant sources of conflict in Nigeria. This terrorist group has been oppressing communities in Northern Nigeria and causing havoc on education and health facilities, attacks on markets and farms, closure of cattle markets, and restricted access to lands. Using data from 2000 to 2020, ICON reports that Boko Haram has killed more than 43,000 Nigerians, and the vast majority of these deaths were women and children.

While there is a lot of attention on Boko Haram and growing attention on farmerherder conflict, it is important to mention that that Boko Haram conflict has expanded beyond terrorism to banditry particularly in the North West. Different groups are also emerging and asking for the right to self-determination. The year 2020 led to a rise of militia groups that target communities in certain states, especially, southern Kaduna state. This new campaign of violence targeting communities has been linked with Fulani militia and may be viewed as an ethnoreligious conflict given the religious and ethnic links.

The heterogeneous conflict in Nigeria and the proliferation of hot spots over time and across regions are our motivation for looking at the impact of conflict in Nigeria holistically. We do not focus on one conflict type but all violent conflict types. However, it is important to note that while most parts of Nigeria have had some exposure to violent conflict since 1960, the intensity of violent conflict exposure varies across regions. The three zones with the highest prevalence rates of conflict over the last few decades are the North East, North Central, and South South regions of Nigeria. It is also worth highlighting that these regions have a significant share of their population working in agriculture.

\footnotetext{
${ }^{9}$ See report, entitled "Nigeria's Silent Slaughter: Genocide in Nigeria and the Implications for the International Community," put together by ICON (International Committee on Nigeria).

${ }^{10}$ Indigene/settler conflicts have also increased and intensified during different times between 1980 and 2015. The violent conflict in Jos in Plateau state in 2001 is one example.
} 


\section{Literature review}

Economic literature focusing on the microeconomic consequences of conflict across African countries has increased in the last two decades. ${ }^{11}$ More recently, there has also been an increase in articles focused on trying to explain the rise in certain types of conflicts within Africa. ${ }^{12}$

Given the pivotal role of agriculture in many developing economies, the effects of idiosyncratic shocks on labor market outcomes have also been examined. For example, there is an established literature on shock events such as bad weather, price, and unemployment shocks, and their effects on off-farm labor supply (Kochar 1999; Rose 2001; Cameron and Worswick 2003; Lamb 2003; Mueller and Quisumbing 2010; Cunguara, Langyintuo, and Darhofer 2011; Mathengea and Tschirley 2015). This strand of literature suggests that farmers increase the supply of off-farm labor under unfavorable conditions in order to maintain consumption levels, which reduces farm work time. ${ }^{13}$ More recently, there is an increasing focus on how conflict as a specific shock affects agricultural-related outcomes (Adelaja and George 2019a; George, Adelaja and Weatherspoon 2020).

With respect to Nigeria, there is a growing literature on the effects of conflict on different economic- and welfare-related outcomes. For example, Nwokolo (2015) used the Nigerian demographic data and ACLED data to examine the effect of Boko Haram Insurgency (BHI) on child health. Child health was also considered by Ekhator-Mobayode and Asfaw (2019). Their study examined the effect of BHI on measures of children's health. Bertoni et al. (2018) examined the impact of civil conflict (specifically Boko Haram) on school attendance and attainment. They found an increase in the number of fatalities to which a child is exposed and a decrease in the number of completed years of education for the cohort exposed to conflict during primary school compared with the non-exposed cohort.

There is also a growing literature on the impact of conflict on food- and agriculture-related outcomes in Nigeria. The effect of conflict on food insecurity was explored by George, Adelaja, and Weatherspoon (2020). They examined the effect of armed conflicts on food insecurity using the General Household Survey (GHS) panel data for Nigeria and Boko Haram terrorist incidence data. They found that an increase in conflict intensity, measured by the number of fatalities, increase in the number of days where the household consumed foods that were less preferred. In addition, they found negative effects on the variety of foods a household consumed and the portion size of the meals. In a related article that focused on food insecurity, using the GHS panel data complemented with a 2017 phone survey, Kaila and Azad (2019) explored the effect of conflict victimization on consumption and food security noting heterogeneity in the effects of conflict. In particular, they found that conflicts involving Boko Haram had more severe negative effects on consumption and food security than conflicts involving the Fulani herdsmen or militant groups in the Niger Delta.

With respect to agricultural-related outcomes, Sidney, Zummo, and Kwajafa (2017) examined the effect of Boko Haram on peasant farmers' productivity in selected

\footnotetext{
${ }^{11}$ See Akresh and de Walque (2008), Minoiu and Shemyakina (2012), and Justino and Shemyakina (2012).

${ }^{12}$ See McGuirk and Nunn (2020) and McGuirk and Burke (2020).

${ }^{13}$ In this article, given the limitations of the dataset we are using, we are unable to explore whether farmers increase their hours of off-farm labor as a response to labor supply reductions on a farm linked with conflict.
} 
localities in Adamawa state (an area that has been directly affected by Boko Haram activities) finding significant negative effects. Adelaja and George (2019b) estimated the causal effects of exposure to attacks on plot ownership, cultivated land, rented land, land values, and cropping patterns. They provided results suggesting that an increase in the intensity of terrorist attacks results in increases in the percentage of land left fallow and increases in the average distance between plots farmed and the homestead, and increases in attacks discourage mono cropping and encourages mixed cropping. They also find that farmers expectations about the values of their lands decreased with increased exposure to violent conflict.

In yet another article, Adelaja and George (2019a) examined the effects of the Boko Haram insurgency on farm output and the demand for farm inputs including the demand for hired labor for harvest operations. Using the same data, their results suggest that violent conflict reduces the hours of hired labor but does not affect the use of family labor, also suggesting that conflict mainly affects hired labor and not family labor. ${ }^{14}$ Mitchell (2019) also used the same data set as Adelaja to estimate the effect of conflict events on household input use, cattle holdings, and cropping decisions. The article differs from the Adelaja and George's article in some of the outcomes considered and the methodology employed to estimate the effect of conflict. Mitchell (2019) also differentiated between the Boko Haram conflict and the Fulani herdsmen conflict. Using an events study framework, he found evidence of negative effects of the Fulani herdsmen conflict on a household's cattle holding in the following season. The author did not find significant effects of the Boko Haram conflict on most of the outcomes considered using the events studies method.

Our article makes use of the same GHS panel data set used by Adelaja and George (2019a and 2019b) and other aforementioned articles. Like these papers, we look at the effect of conflict at an area level (LGA or EA). However, our research differs from most of the articles discussed because these studies either focus on the effect of the Boko Haram insurgency or compare the effects of that insurgency with those of the Fulani herdsmen conflict. In contrast, we take a more generalized approach. We believe that this approach is justified given the prolonged exposure to violent conflict in different parts of Nigeria and the potential value of exploring the average treatment of conflict in Nigeria on the labor supply of agricultural households. Moreover, we focus on the overall effect of violent conflict in Nigeria, both recent and accumulated. To the best of our knowledge, our article is the first that has attempted to explore both the longterm and short-term effects of conflict in Nigeria on labor supply. Furthermore, another unique aspect of our article is that we complement the covariate conflict exposure measure with household-level idiosyncratic shocks. Controlling for households' idiosyncratic shocks attenuates bias in estimated effects and differentiates our article from the aforementioned articles that assigned conflict at the community level or LGA and did not control for other idiosyncratic shocks. ${ }^{15}$

\section{Conceptual framework: labor supply and conflict}

Labor-described as human effort-is about the most easily available resource used by households in rural settings whether for on-farm activities, participation in off-farm

\footnotetext{
${ }^{14}$ Our results for violent conflict in Nigeria as a whole contradicts this finding.

${ }^{15}$ Only Kaila and Azad (2019) consider the impact of conflict at the individual level. However, the endogenous nature of individual-level exposure to conflict could bias their estimated coefficients.
} 
labor activities, or the allocation of labor across various livelihood activities. Interactions between individuals and groups can lead to conflict and such conflict can be violent with "dramatic consequences on human well-being" (Hsiang, Burke, and Miguel 2013). Through direct and indirect channels, violent conflict can impact the labor supply outcomes of households and individuals exposed to violence. First, violent conflict leads to fatalities and injuries. This exogenous shock directly affects a household's labor stock and households can experience labor shortage because certain household members are no longer participating in the labor force due to fatality or injury from conflict. The labor shortage could also be reflected in the total decrease in hours worked by the household. In particular, injury can reduce the time available to work as individuals may be temporarily disabled or need to take time to recover, which directly translates to loss of labor hours on the farm.

Another channel that can lead to labor supply shortages for farm households is the destruction of farms. The destruction of farm lands (e.g., through burning or theft of crops, looting of cattle, etc.) and other productive assets can discourage households from supplying more hours of labor to agriculture activity, given the unpredictability in return linked with unexpected violent attacks and looting. Furthermore, violent conflict can precipitate fear in individuals exposed to it. In this scenario, farmers are afraid to leave their homes and to cultivate more isolated farm plots. Violent conflict also leads to displacement. Displacement can be long term or short term. In either cases, farmer households' labor supply is disrupted as families are forced to migrate and total hours dedicated to farm activity declines. ${ }^{16}$

The aforementioned pathways are likely to induce drops in agricultural production or output. We hypothesize that this decline in agricultural output will consequently force households to seek employment outside of agriculture in order to smooth consumption or income. Similar to the discouraged worker effect of unemployment shocks, small holder farmers could decrease their labor force participation in response to agricultural losses or decrease the hours dedicated to farm work. However, the overall effect on a household's labor supply is an empirical question. The overall effect on labor participation of agricultural households will depend on farmers' prevailing conditions. If farmers are less able to migrate and more credit constrained and workers supply labor less elastically, then the overall labor supply response might turn out to be negative. However, if there is ample opportunity for off-farm employment or labor markets are not closed or are not too dangerous to travel to, then this will give rise to a positive labor supply response. Fernández, Ibáñez, and Peña (2014) noted that if labor markets were available, then the occurrence of a violent shock would render on-farm work less profitable and market work more attractive. However, we are of the opinion that since violent conflict often affects several markets, including the off-farm labor market, we hypothesize an overall negative labor supply response of violent conflict exposure. ${ }^{17}$

Intrahousehold substitution effect can also arise from a violent conflict shock. The "added worker effect" hypothesis in the labor economics literature predicts that the labor force participation rate among women is expected to increase as women have to enter the labor force to substitute for the labor of men who were killed, injured,

\footnotetext{
${ }^{16}$ Although we can hypothesize based on prima facie evidence, due to data limitations, we are unable to identify which of the aforementioned pathways is the primary driver of the decline in labor within our data.

${ }^{17}$ We are not able to test this hypothesis in our article because of the limitations of the LSMS data, in particular, the lack of comprehensive information on hours spent on other productive activities in the 2010 and 2012 LSMS survey.
} 
and migrated or displaced as a result of exposure to violent conflict. As noted in Justino and Shemyakina (2012), the death of working age household head may lead to changes in the household reallocation of labor, for example, women and children replacing lost workers. In this article, we will check for evidence of intrahousehold labor reallocation. We focus on testing for changes in the hours of labor supplied of a household head, spouse, children, and relatives separately.

\section{Empirical strategy}

To answer both questions of interest, we estimate the impact of armed conflict on hours of labor supplied on the farm. We make use of two estimation strategies. First, we explore a Heckman selection model given the potential of self-selection bias. We consider this as the baseline model. Our second and preferred estimation strategy is a fixed effects (FE) approach exploiting the panel nature of our data. The Heckman selection model includes two separate equations. The first is the sample selection equation, focused on selection into labor force participation. For this equation, our dependent variable is a dummy variable and it takes the value of 1 if a household head participates in the labor force and 0 otherwise. The second equation is the main equation linking the covariate of interest-violent conflict to the outcome variable-hours of farm labor supply. We estimate the Heckman model multiple times changing our measure of hours of farm labor. First, we consider the total family farm labor supply and then we consider separately farm labor supply by household head, spouse, children, and finally relatives. ${ }^{18}$

For our first question, our main independent variable and our measure of the intensity of exposure to conflict are based on recent violent deaths in a household's LGA. We refer to this as recent conflict exposure. ${ }^{19}$ For our second question, we focus on accumulated exposure to conflict from 1997 to the year of the survey. ${ }^{20}$ We refer to this conflict measure as long-term/accumulated conflict exposure.

In both equations, we include a series of control variables. In particular, based on past literature that established a relationship between weather/climate variables and rural labor markets (Jessoe, Manning, and Taylor 2018), we control for plot characteristics, the nutrient availability of the soil, annual mean temperature, and annual rainfall. We also control for community characteristics that vary at the local government area level used to control for the demand-side factors regarding the availability of off-farm work. These variables include distances to major roads, population centers, market, and border and administrative centers. In addition, we control for household characteristics to account for household preferences, in particular, we include age and age squared, the level of education of the household head, gender, and household size. Given the importance of health and labor supply, we control for health using two variables. The first captures if an individual has had any illness or injury during the past 4 weeks preceding the survey. The second variable tries to get at the severity of past illness that could have a more significant effect on labor supply. The variable captures if an individual has been hospitalized in the last 12 months. We also control for exposure to idiosyncratic shocks. Following Kochar (1999) and Rose (2001), we also control for market

\footnotetext{
${ }^{18}$ Since we have two ways, we construct conflict exposure, and five different measure, of farm labor supply, we run the Heckman model 10 times.

${ }^{19}$ We provide a detailed description of how this variable is measured in data and descriptive analysis.

${ }^{20}$ Our accumulated exposure measure begins in 1997 because that was the year the ACLED data were first collected for Nigeria.
} 
wage. Other variables included to control for household wealth are the value of land (self-reported by farmers) and the use of land size and agricultural wage as controls for aggregate consumption. We also include state fixed effects and interaction between zone and time fixed effects.

For a more robust identification, the selection equation should have at least one variable that is not in the outcome equation. This imposes the exclusion restriction. In an ideal case, the variable has a non trivial impact on the probability of labor force participation. For our analysis, we use the total number of conflict events in a LGA from 1997 until the year of the survey. Our argument is that these accumulated events provide institutional history and a rough measure of the stability of the LGA which could affect if an individual participates in the labor force. However, we do not expect that history would directly affect the hours an individual will choose to work currently (hence its non inclusion in the outcome equation).

While the Heckman selection model can attenuate issues of self-selection bias, its limitations in addressing potential endogeneity issues and the difficulty in making the case that our exclusion restriction is valid lead us to our preferred estimation strategy, the fixed effects (FE) approach. ${ }^{21}$ The FE model can be specified as follows:

$$
H_{i j t}=\beta_{0}+\text { ConflictEXP }_{\mathrm{jt}} \beta_{1}+\mathbf{x}_{\mathrm{ijt}} \rho+\mathbf{c}_{\mathrm{ijt}} \beta_{2}+\gamma_{t}+\delta_{i}+\psi_{z t}+\epsilon_{i j t}
$$

$H_{i j t}$ is the total family hours of labor worked in household $i$ in LGA $j$ and year t. ConflictEXP $\mathbf{P}_{\mathbf{j t}}$ is a measure of violent conflict in LGA $\mathbf{j}$ and year t. $\mathbf{x}_{\mathbf{i j}}$ is a vector of individual and household variable regressors that affect the number of hours worked and $\mathbf{c}_{\mathrm{ij}}$ represents time-varying local government area characteristics such as the rainfall levels, population density, nutrient availability in plots, and temperature. $\delta$ are timeinvariant household-specific effects that could be correlated with the observed covariates and also include state fixed effects; $\gamma_{t}$ are year fixed effects; $\psi_{z t}$ are interactions of zone and year dummies to control for time-varying zone effects; $\epsilon_{i j t}$ is the idiosyncratic error term. $\beta_{1}$ is the parameter of interest to be estimated and captures the effect that exposure to conflict has on labor supply. ${ }^{22}$

Using panel data and a fixed effect strategy attenuates biases in coefficients and increases the likelihood that estimated effects are consistent. The fixed effect approach accounts for time-invariant characteristics of households that could be correlated with conflict and also correlated with our variable of interest-hours worked on farm. Hence, biases emanating from household heterogeneity are attenuated with this method. While the fixed effect strategy cannot remove biases stemming from unobserved time-varying household characteristics, we can attenuate this kind of bias by including as many time-varying controls as possible in our analysis. ${ }^{23}$

It is useful to mention that reverse causality and simultaneity can hinder deriving consistent estimates even when a fixed effects strategy is used for estimating the effect of conflict. In the case of the question we are interested in, we do not worry as much about reverse causality, even though we cannot rule it out. In particular, in both the questions, we consider, we are looking at the effect of past conflict on current farm

\footnotetext{
${ }^{21}$ The results from the estimation of the selection equation show a negative coefficient for the excluded variable, but the coefficient was not statistically significant, which casts a doubt on its validity.

${ }^{22}$ We include similar variables as controls in both our Heckman model and our fixed effect model.

${ }^{23}$ In every regression, we cluster the standard errors at the level of the household to allow household decisions to be correlated over time.
} 
labor supply. It is harder to argue that an individual's current farm labor supply is causing a change or driving their past accumulated conflict exposure.

\section{Data and descriptive analysis}

The socioeconomic data used in this study are the Nigeria General Household Survey (GHS). As noted on the World Bank's Central Microdata Catalog website, “The GHS is implemented in collaboration with the World Bank Living Standards Measurement Study (LSMS) team as part of the Integrated Surveys on Agriculture (ISA) program and was revised in 2010 to include a panel component (GHS-Panel)". ${ }^{24}$ The survey was undertaken by the National Bureau of Statistics in partnership with the Federal Ministry of Agriculture and Rural Development (FMARD), the National Food Reserve Agency (NFRA), the Bill and Melinda Gates Foundation (BMGF), and the World Bank (WB).

All sampled households were administered a multitopic household questionnaire. The questionnaire geo-references the dwelling's location and collects individual-disaggregated information on demographics, education, health, employment, anthropometrics, various income sources, housing, food and nonfood consumption and expenditures, and asset ownership. There is also an agricultural questionnaire module with observations on geo-referenced plot locations and Global Positioning System (GPS)-based plot areas, plotlevel information on input use, cultivation, and production (the household members who manage and/or own each plot and individual-disaggregated labor input at the plot level. The survey information is provided for postplanting/preharvest and the postharvest outcomes. The GHS Panel is a nationally representative survey of approximately 5,000 households, which is also representative of the geopolitical zones in Nigeria at both the urban and rural levels. There are four waves currently of the panel $(2010,2012,2015$, and 2018) and we used the labor file questions in the agricultural and household modules. The labor file in the agricultural module that we used for the analysis of labor supply in terms of hours worked provides information on the total hours of work supplied to farm work during the harvest season. The file is disaggregated across hours of labor work for the household head, the spouse, the children, and the relatives. To arrive at total hours of work supplied by farm families, we added hours of work supplied by each household member including the relatives. While the labor file in the agricultural module focused on the hours of labor supplied by farm families at the plot level and disaggregated across household members, the labor file in the household module focused on the different employment status of households without a clear demarcation of the hours worked across wage employment, farm employment, and off-farm employment particularly for Waves 1 and 2. We used the labor file in the agricultural module in analyzing the hours of labor supplied by agricultural households while we used the labor file in the household module in analyzing the labor participation of agricultural households.

Despite the availability of the four waves, we made use of the first three waves in our analysis because of an observed significant inconsistency in the labor file for wave 4 compared with the earlier waves of the survey. For example, in wave 4, the labor time is not disaggregated by household head, spouse, children, and relative, which was available in the first three waves and is of interest to us. In addition, wave 4 does

\footnotetext{
${ }^{24}$ The World Bank in its description of the data also notes that the panel data survey was launched for tracking farm and rural households' social economic changes over time. See Nigeria National Bureau of Statistics (2018a), (2018b) (2018c) and (2019).
} 
not provide information on labor time in weeks. In waves 1,2 , and 3, the labor file has information on the number of weeks, days, and hours of work, disaggregated by household head, spouse, children, and relatives. These shortcomings in how the data were collected in wave 4 make it impossible to construct labor supply for household heads, spouse, children, and relatives in similar ways we were able to do so in the first three waves.

For our analysis, we derived the total hours worked by household heads by combining the hours worked on each plot. The hours worked on each plot is derived using information from the harvest survey. Information is collected on the number of hours worked on the plot, the number of days worked on the plot, and the number of weeks worked in the season on the plot. The data set also includes a number of specific household and individual characteristics that we include as controls. ${ }^{25}$

To measure conflict exposure, we turn to the Armed Conflict Location and Event Data (ACLED) by Raleigh, Hegre, and Carlson (2010). This database focuses on a range of violent and nonviolent actions by governments, rebels, militias, communal groups, political parties, rioters, protesters, and civilians. It records event date, event type, location, and conflict fatalities and covers the period from 1997 to 2021 for all countries including Nigeria. ${ }^{26}$ Following Odozi and Oyelere (2019), we use these data to construct two measures of conflict exposure using fatalities at the local government area level. We also create a conflict event measure using the ACLED data. This measure captures all the conflict events in a LGA. Figure 1 provides a map of accumulated conflict events in LGA in Nigeria from 1997 to 2018. We present these data visually in Figure 1 to provide readers with a visual representation of the intensity and widespread nature of conflict events in Nigeria. Notice that most parts of Nigeria have experienced violent conflict events, and a fewer number of locations have had a very high number of conflict events over time.

Figure 2 shows conflict events in different periods of time over 10 years. This evolution-style map of conflict events shows that the number of conflict events has been increasing in different communities in Nigeria and the location of these events exhibits significant heterogeneity over time. ${ }^{27}$

While conflict events have been frequently used by many past researchers to proxy for conflict exposure, we do not follow this approach. We are interested in the intensity of impact, which we argue is better captured by violence-related fatalities. Hence for measuring recent exposure in our analysis, we consider the total number of conflict-related fatalities in the local government in the year of the survey plus the two years preceding it. We choose to construct our recent measure as noted above because households' responses to shocks such as violence related fatalities are not knee jerk and are too often delayed. ${ }^{28}$ To capture these potential nuances in how violent conflict exposure directly or indirectly can alter decision making, we use conflict deaths over a wider range of time to measure recent intensity of exposure. For the long-term

\footnotetext{
${ }^{25}$ For our analysis, we restricted our sample to household heads in agricultural households who participated in labor supply during the survey. We also restricted our analysis to the balanced panel of the sample.

${ }^{26} \mathrm{We}$ make use of data from 1997 to 2016.

${ }^{27}$ While we present conflict events or fatalities up until 2018 in Figures 1-4, we limit our analysis to the first three surveys. We are unable to use the more recent conflict data from 2016 to 2018 in our analysis because we do not include wave 4 of the household survey for reasons mentioned above.

${ }^{28}$ In some cases, a farmer may choose to reduce labor on a plot not after one incidence of violence in the LGA but after a series, or after a long enough period of violence, or after observations in the next planting season that would affect labor supply during the next harvest season.
} 


\section{Long Conflict Exposure \\ Events, 1997-2018}

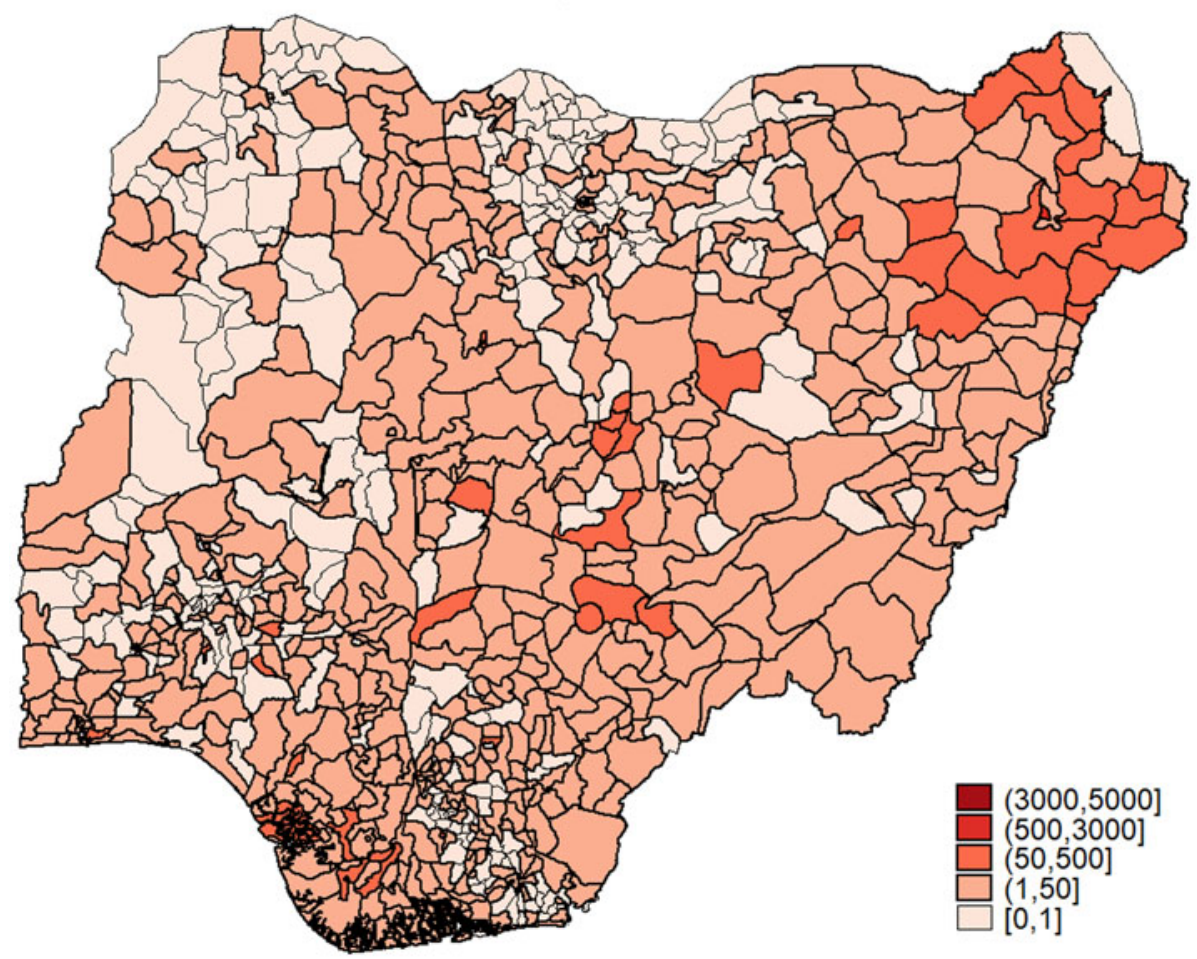




\section{Recent Conflict Exposure}
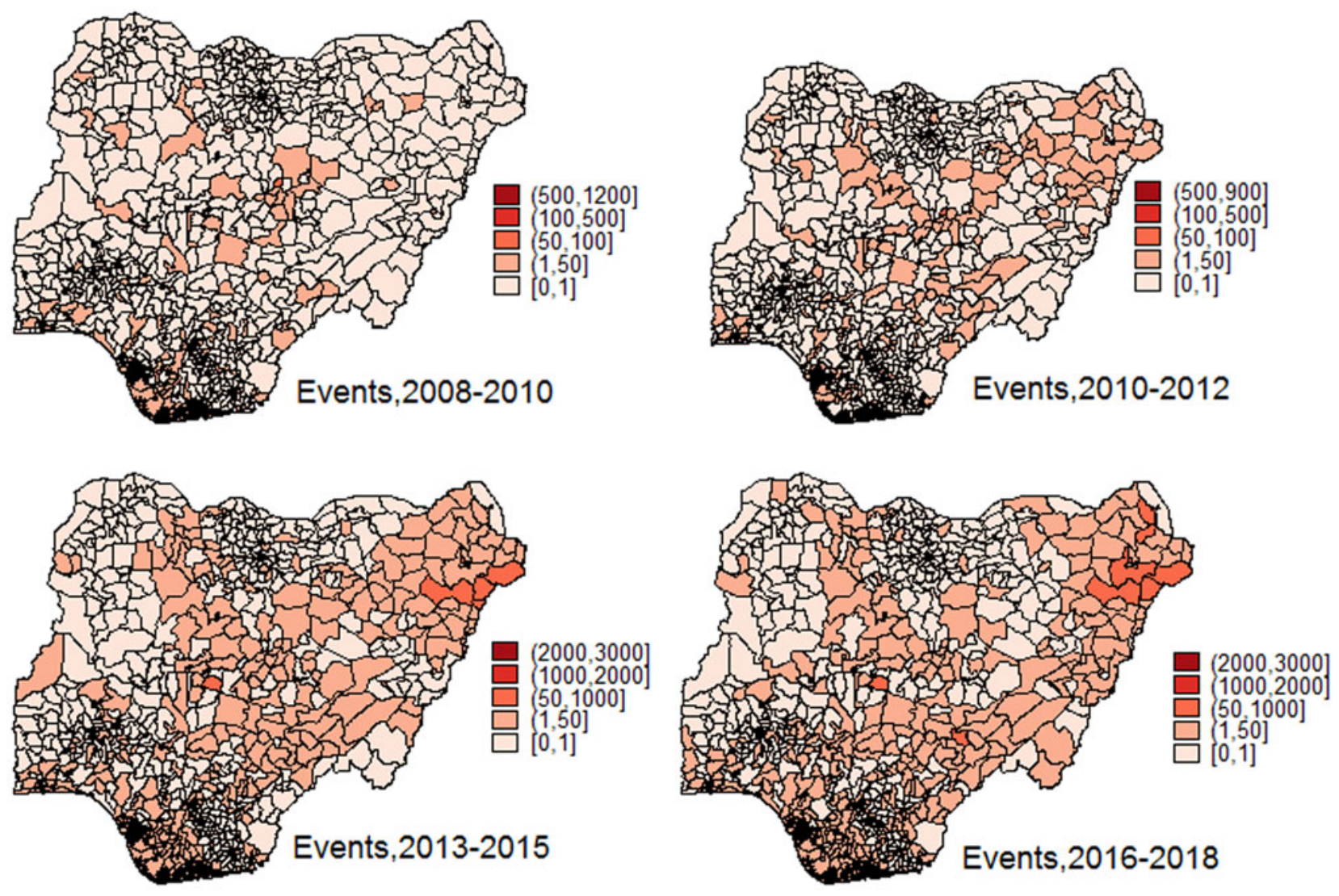

Fig. 2. Evolution of Conflict Event in Nigeria 1997-2018. 
measure of conflict, we consider the total number of conflict related fatalities in the local government area in the year of the survey plus all other preceding years of available data (1997 to the year of the survey). We normalize these two measures using projected population figures for the local government for the respective survey years to better capture the intensity of exposure in a community. For example, 10 conflict related fatalities in a low-population LGA is clearly going to have more impact than 10 fatalities in a high-population LGA. ${ }^{29}$

Figure 3 provides a mapping of total violent fatalities in Nigeria from 1997 to 2018. This map provides extra support as to why we take the approach of estimating the average effect of violent conflict in Nigeria. Notice that a significant part of the country has been exposed to violent conflict as captured by fatalities in different parts of the country. Figure 3 also highlights that the zones with the most intense conflict exposure in Nigeria are the North East, the South South and the North Central parts of Nigeria. Figure 4 shows four maps of Nigeria designed to capture how conflict fatality has evolved over the 2008-2018 period. Notice over time that not only has the locations experiencing fatalities increased, the areas with the most intense conflict exposure in terms of fatalities have changed.

Figures 1-4 provide further support for our approach. We focus on estimating the overall effect of conflict in Nigeria given its widespread prevalence rather than focus solely on the effect of particular conflicts on households exposed to it. Apart from the ACLED data, we also made use of information on rainfall and population density in our analysis. We obtained rainfall data from the Central Bank of Nigeria (CBN) annual statistics for 2016. Information on land surface area and population for each state was sourced from the National Population Commission.

\section{Results}

Tables 1 and 2 present summary statistics of the variables used in the regression analyses. In Table 2, we present summary statistics of some of our key dependent variables for the balanced and unbalanced panel data. Table 2 shows that 91 percent of farm household heads supplied labor in 2010, but this figure declined slightly in 2012 and 2015 , respectively, to 90 percent and 87 percent. Total labor hours supplied by household heads to harvest season farm work were on average $540.19 \mathrm{~h}$ in 2010 . This share increased in 2012 to $556.06 \mathrm{~h}$ but declined to $476.31 \mathrm{~h}$ in 2015 . We find a substantial decline in total hours of work for spouses and children across years. While spouses supplied $319.41 \mathrm{~h}$ of labor in 2010 , hours declined, respectively, to $299.30 \mathrm{~h}$ and $266.28 \mathrm{~h}$ in 2012 and 2015.

Table 1 also shows that on average, conflict exposure increased from 2010 to 2015. An interesting observation from Table 1 is the percentage of households that are exposed to idiosyncratic shocks in the past year. This share increased between 2010 and 2012 but decreased to its 2010 levels by 2015 .

The results of our baseline model (Heckman selection) can be found in Tables A1 and $\mathrm{A} 2$ of the appendix of the article. In Table A1, we focus on the effect of the recent violent conflict exposure on the hours worked for farm households, while in Table A2, we summarize the results focused on the effects on labor supply of accumulated longterm conflict exposure. Part A of these tables presents results for select variables from

\footnotetext{
${ }^{29} \mathrm{We}$ construct our conflict measures as percentages of the population in each LGA to better get at the intensity of effect and also to ease interpretation.
} 


\section{Long Conflict Exposure}

Fatalities,1997-2018

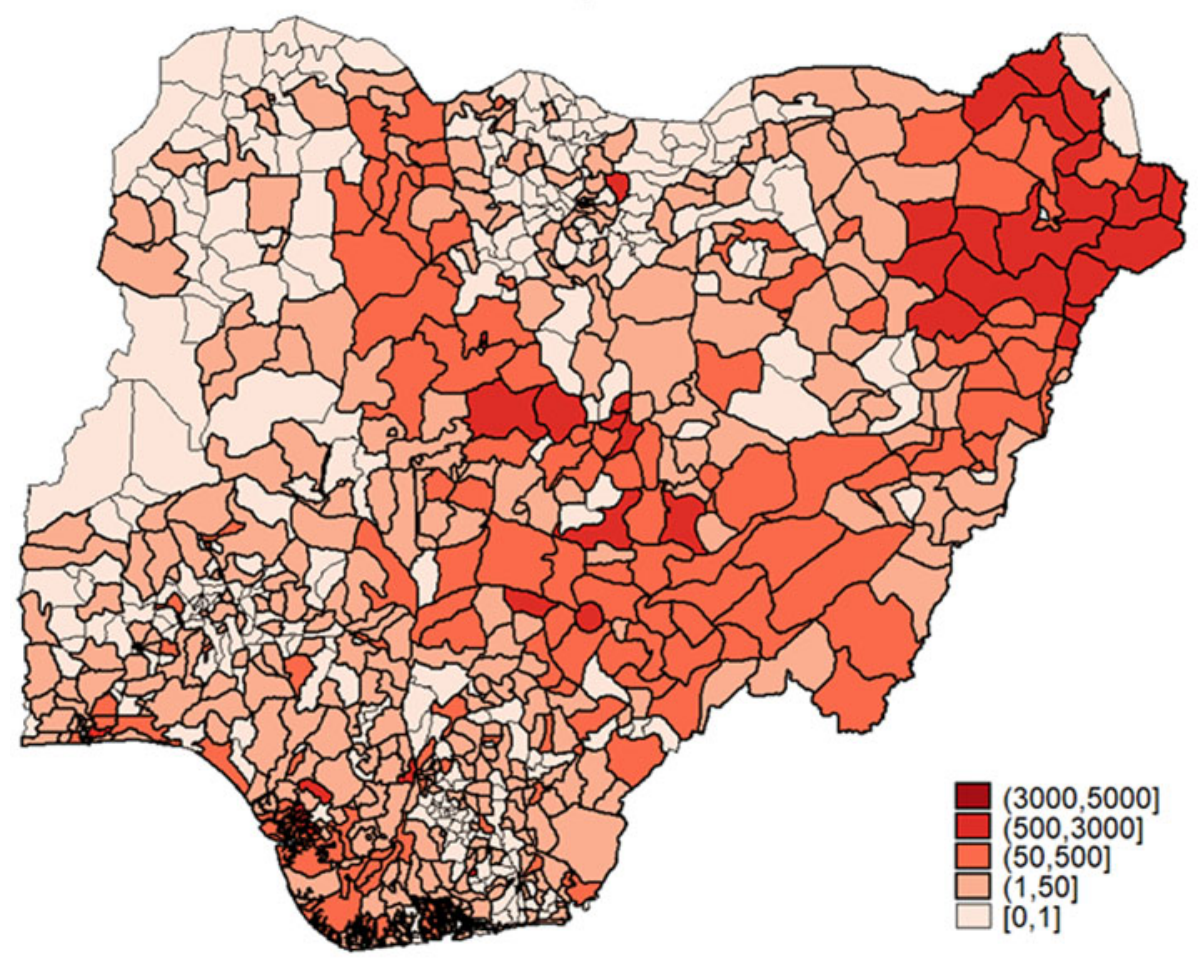

ஸे

กิ

옹.

हี

?

C

苛

$\frac{0}{2}$ 


\section{Recent Conflict Exposure}
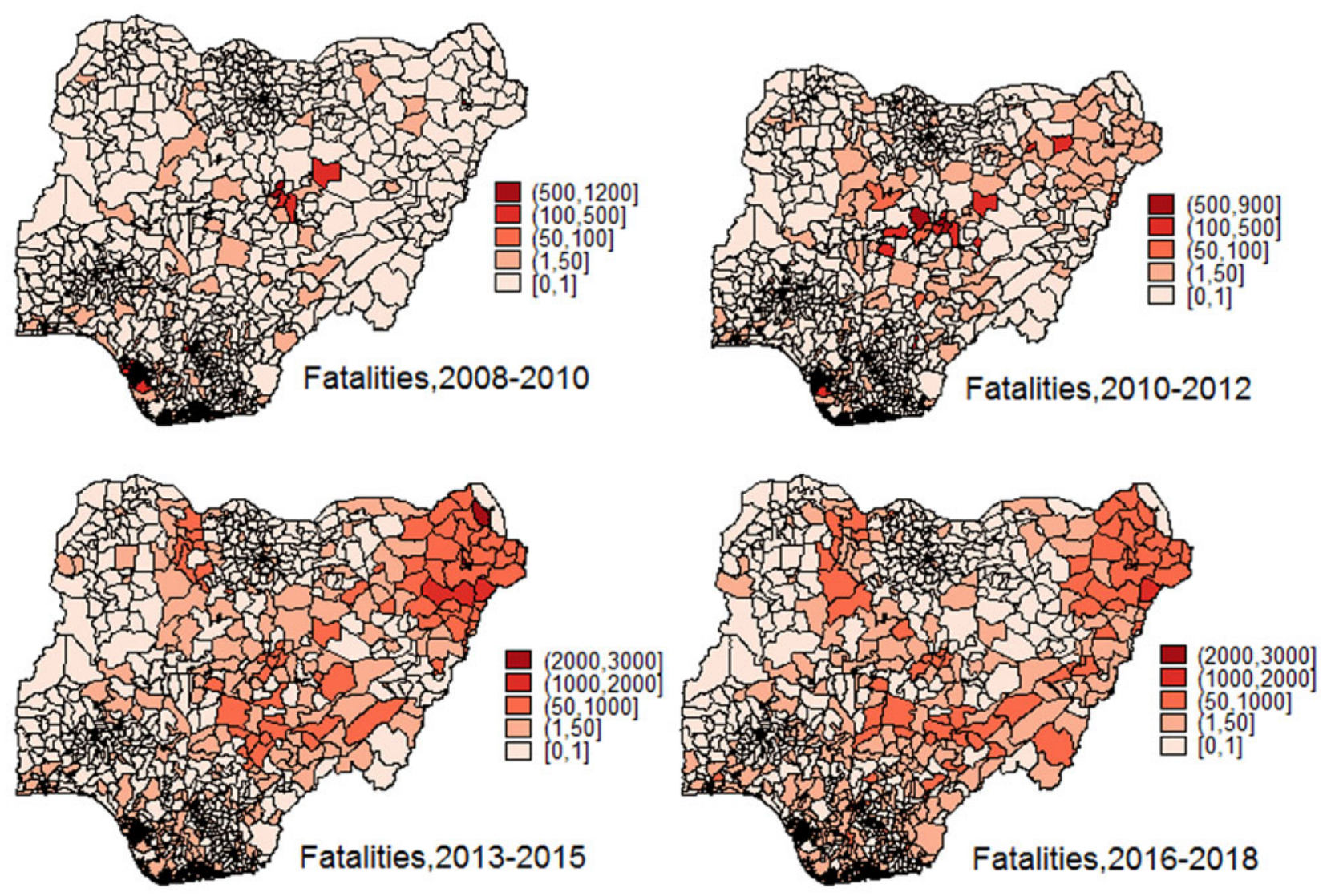
Table 1. Summary statistics

\begin{tabular}{|c|c|c|c|c|c|c|}
\hline \multirow{2}{*}{ Variables } & \multicolumn{2}{|c|}{2010} & \multicolumn{2}{|c|}{2012} & \multicolumn{2}{|c|}{2015} \\
\hline & \multicolumn{2}{|c|}{$N=5,009$} & \multicolumn{2}{|c|}{$N=4,807$} & \multicolumn{2}{|c|}{$N=4,622$} \\
\hline Prop labor force & 0.91 & 0.28 & 0.90 & 0.30 & 0.87 & 0.34 \\
\hline Total hours worked (Head) & 540.19 & $1,736.10$ & 556.06 & $2,938.72$ & 476.31 & $1,169.58$ \\
\hline Total hours worked (Children) & 181.03 & $2,271.06$ & 138.34 & 538.87 & 129.80 & 599.01 \\
\hline Total hours worked (Relatives) & 62.98 & 285.23 & 71.34 & 402.27 & 52.71 & 257.95 \\
\hline Total hours worked & $1,206.69$ & $5,616.96$ & $1,317.46$ & $5,428.83$ & $1,065.69$ & 2683.21 \\
\hline Recent event per LGA & 1.527 & 5.474 & 2.818 & 15.843 & 4.900 & 13.529 \\
\hline Long-term event per LGA & 4.389 & 14.442 & 6.033 & 23.361 & 12.021 & 39.934 \\
\hline Age in years & 50.20 & 15.21 & 52.37 & 14.90 & 53.01 & 14.55 \\
\hline Age squared & $2,751.16$ & $1,653.92$ & $2,964.45$ & $1,681.81$ & $3,021.44$ & $1,633.51$ \\
\hline Years of schooling & 6.81 & 5.64 & 6.74 & 5.79 & 7.21 & 5.81 \\
\hline Household size & 5.84 & 3.02 & 6.31 & 3.11 & 7.02 & 3.46 \\
\hline Distance to major road $(\mathrm{km})$ & 7.99 & 12.19 & 7.80 & 11.81 & 7.63 & 11.66 \\
\hline
\end{tabular}




\begin{tabular}{|c|c|c|c|c|c|c|}
\hline Distance to pop center (km) & 19.40 & 17.61 & 18.96 & 17.59 & 18.85 & 17.70 \\
\hline Distance to market $(\mathrm{km})$ & 62.85 & 44.39 & 63.39 & 44.97 & 62.88 & 45.32 \\
\hline Distance to border post $(\mathrm{km})$ & 294.77 & 181.24 & 292.46 & 180.07 & 292.19 & 180.99 \\
\hline Annual mean temperature & 263.42 & 9.59 & 263.44 & 9.58 & 263.42 & 9.45 \\
\hline Annual precipitation (mm) & $1,471.40$ & 633.01 & $1,475.05$ & 627.56 & $1,486.46$ & 626.58 \\
\hline Population density & 304.28 & 343.58 & 319.43 & 362.25 & 344.40 & 392.71 \\
\hline Farm daily wage (male) & $1,904.86$ & $4,915.74$ & $1,980.19$ & $4,633.89$ & $1,936.15$ & 4467.16 \\
\hline
\end{tabular}


Table 2. Summary statistics additional variables

\begin{tabular}{|c|c|c|c|c|c|c|}
\hline \multirow[b]{3}{*}{ Variables } & \multicolumn{2}{|c|}{2010} & \multicolumn{2}{|c|}{2012} & \multicolumn{2}{|c|}{2015} \\
\hline & \multicolumn{2}{|c|}{$(N=4,137)$} & \multicolumn{2}{|c|}{$(N=4,132)$} & \multicolumn{2}{|c|}{$(N=4,054)$} \\
\hline & Mean & St. Dev. & Mean & St. Dev. & Mean & St. Dev. \\
\hline \multicolumn{7}{|l|}{ Balanced panel } \\
\hline Prop labor force & 0.91 & 0.28 & 0.90 & 0.30 & 0.88 & 0.33 \\
\hline Total hours worked (Head) & 541.75 & $1,739.77$ & 558.57 & $2,954.04$ & 477.88 & 1174.46 \\
\hline Total hours worked (Spouse) & 319.78 & $1,055.75$ & 301.42 & 914.39 & 271.53 & 766.96 \\
\hline Total hours worked (Children) & 181.38 & $2,276.10$ & 139.56 & 541.55 & 133.99 & 613.78 \\
\hline Total hours worked (Relatives) & 62.92 & 285.21 & 71.88 & 404.34 & 54.51 & 262.80 \\
\hline \multirow[t]{2}{*}{ Total hours worked } & $1,156.18$ & $4,709.72$ & $1,332.30$ & $5,671.86$ & $1,089.92$ & 2751.85 \\
\hline & \multicolumn{2}{|c|}{$(N=5,009)$} & \multicolumn{2}{|c|}{$(N=4,807)$} & \multicolumn{2}{|c|}{$(N=4,622)$} \\
\hline Variables & Mean & St. Dev. & Mean & St. Dev. & Mean & St. Dev. \\
\hline \multicolumn{7}{|l|}{ Unbalanced panel } \\
\hline Prop labor force & 0.91 & 0.28 & 0.90 & 0.30 & 0.87 & 0.34 \\
\hline Total hours worked (Head) & 540.19 & $1,736.10$ & 556.06 & $2,938.72$ & 476.31 & 1169.58 \\
\hline Total hours worked (Spouse) & 319.41 & $1,053.79$ & 299.30 & 909.89 & 266.28 & 752.13 \\
\hline Total hours worked (Children) & 181.03 & $2,271.06$ & 138.34 & 538.87 & 129.80 & 599.01 \\
\hline Total hours worked (Relatives) & 62.98 & 285.23 & 71.34 & 402.27 & 52.71 & 257.95 \\
\hline Total hours worked & $1,206.69$ & $5,616.96$ & $1,317.46$ & $5,428.83$ & $1,065.69$ & $2,683.21$ \\
\hline
\end{tabular}

the participation equation and part B summarizes select results for the main outcome equation. In columns (1) of both tables, we present the result for the household head. In columns (2), we present the results for spouse hours, column (3) children, column (4) relatives. In column (5), the result for the total hours worked for the entire household is presented. $^{30}$

As we noted in our empirical section, we include accumulated conflict events in an LGA from 1997 to the survey year in our participation equation, but we exclude it from our outcome equation. We worry about the estimated effects from this model because the excluded variable, though negative, is not statistically significant in our selection equation in both Tables A1 and A2. This finding casts a doubt on the validity of this exclusion restriction since the variable should have a nontrivial impact on the probability of selection. Furthermore, the Wald test of the independence of equations suggests that using a Heckman selection model may not be necessary as we fail to reject the hypothesis that $\rho=0$ in all but one subsample (relatives). Hence, the hypothesis that the two equations are independent cannot be rejected. Given the aforementioned limitations, we review the Heckman results with caution as these estimates could be biased and not consistent.

\footnotetext{
${ }^{30}$ This includes household head, spouse, children, and relatives.
} 
The results from the outcome equation in Tables A1 and A2 part B column (5) suggest that an increase in exposure to conflict is negatively correlated with hours of farm family labor supplied. To get at the potential heterogeneity within the household in this effect, we focus on the results summarized in columns (1)-(4). These results suggest that an increase in exposure to conflict is correlated with a statistically significant decline in the hours the household head worked on the farm. We do not note any significant effects for the hours worked by spouse, children, and relatives.

In Tables 3 and 4, we present the labor supply estimates using our fixed effects (FE) model, which is our preferred empirical strategy. As noted in the empirical section of the article, the FE model controls for time invariant unobservable household-level characteristics, which attenuates bias in the estimated effects of conflict on labor supply (hours worked). To further reduce the potential bias linked with time-varying unobservables correlated with our conflict measure and farm labor supply, we include several controls. In particular, we include in our analysis several time varying controls such as idiosyncratic shocks, health-related variables, controls for time-varying social characteristics of the LGA, precipitation, average farm wages, and population density. We also include year and zone fixed effects and zone and year interactions.

In Table 3, we present the results for total hours worked for the entire family on plots in the harvest season. In column (1) of Table 3, we present the results using the recent conflict measure, and in column (2), we present the results using the long-term measure of conflict. The results suggest a significant negative effect of conflict exposure on the total hours of labor on the farm for a family. The results of the test for heterogeneity across family members are summarized in Table 4. In Column (1) of Table 4, we present the results for the model with the number of hours worked by the household head as the dependent variable. In column (2), the dependent variable is the number of hours worked by spouse. In column (3), the dependent variable is hours worked by children and in column (4), the dependent variable is the hours worked by relatives. In Panel A, we present the relevant estimates using the recent exposure to conflict measure, and in Panel $\mathrm{B}$, we present the estimates using the long-term accumulated exposure to conflict measure. The results summarized in Table 4 suggest that exposure to conflict (recent or over a long time), reduces the hours worked significantly for household heads. We do not find any significant effect on labor of spouse, children or relatives. Given this finding, it is reasonable to infer that the noted decline in the total farm labor supply of households is driven by a decline in the labor supply of household heads.

Comparing our preferred estimates with our baseline model (Heckman), we notice that the estimates using the Heckman model are mostly consistent in inference with the results from our preferred model (fixed effects). In particular, for families' total labor supply, our fixed effects model suggests significant negative effects of both recent and long-term conflict exposure. In contrast with the Heckman model, we only find significant negative effects on total family labor supply using the long term measure. For household heads, both model estimates suggest that exposure to conflict (recent or over a long time) reduces hours supplied on the farm significantly. For hours worked by children and spouse, both methods do not find evidence of significant negative effects of recent or longer term exposure to conflict. For hours supplied on farm by relatives, we also note no significant effects using our preferred method. However, the estimates using the baseline model suggest a significant negative correlation with the longer-term exposure measure but not using the recent exposure measure.

It is worth noting that our results are in contrast with Adelaja and George (2019a) who do not find a significant effect of the Boko Haram conflict on the total family 
Table 3. The effect of violent conflict on a family total labor supply during harvest season

\begin{tabular}{|c|c|c|}
\hline & (1) Recent conflict b/se & (2) Long conflict b/se \\
\hline \multirow[t]{2}{*}{ Conflict recent death as $\%$ of LGA } & & $-2,067.368^{\star}$ \\
\hline & & $(1,099.191)$ \\
\hline \multirow[t]{2}{*}{ Conflict long-term death as $\%$ of LGA } & $-1,864.661^{\star \star \star}$ & \\
\hline & $(702.282)$ & \\
\hline \multirow[t]{2}{*}{ Exposed to shock } & -100.119 & -99.807 \\
\hline & $(167.526)$ & $(167.442)$ \\
\hline \multirow[t]{2}{*}{ Age } & 35.702 & 34.181 \\
\hline & $(40.102)$ & $(40.108)$ \\
\hline \multirow[t]{2}{*}{$\mathrm{Age}^{2}$} & -0.111 & -0.100 \\
\hline & $(0.412)$ & $(0.412)$ \\
\hline \multirow[t]{2}{*}{ Years of schooling } & -31.768 & -31.803 \\
\hline & $(26.623)$ & $(26.637)$ \\
\hline \multirow[t]{2}{*}{ Household size } & -4.918 & -7.486 \\
\hline & $(41.720)$ & $(41.910)$ \\
\hline \multirow[t]{2}{*}{ Pop density } & -0.190 & -0.169 \\
\hline & $(1.026)$ & $(1.027)$ \\
\hline \multirow[t]{2}{*}{ Value of land self-reported by households } & $0.000^{\star}$ & $0.000^{*}$ \\
\hline & $(0.000)$ & $(0.000)$ \\
\hline \multirow[t]{2}{*}{ Distance to major road } & -0.590 & -0.594 \\
\hline & (3.097) & $(3.101)$ \\
\hline \multirow[t]{2}{*}{ Distance to population center } & -1.586 & -1.530 \\
\hline & $(2.853)$ & $(2.851)$ \\
\hline \multirow[t]{2}{*}{ Distance to market } & 44.830 & 46.112 \\
\hline & $(36.229)$ & $(36.258)$ \\
\hline \multirow[t]{2}{*}{ Distance to border post } & -3.357 & -3.334 \\
\hline & $(2.952)$ & $(2.952)$ \\
\hline \multirow[t]{2}{*}{ Distance to administrative center } & 0.576 & 0.507 \\
\hline & $(3.047)$ & $(3.042)$ \\
\hline \multirow[t]{2}{*}{ Annual mean temperature } & -12.559 & -11.778 \\
\hline & $(25.460)$ & $(25.449)$ \\
\hline \multirow[t]{2}{*}{ Annual mean precipitation } & 4.810 & 4.864 \\
\hline & $(4.173)$ & $(4.181)$ \\
\hline \multirow[t]{2}{*}{ Nutrient availability } & -41.534 & -38.112 \\
\hline & $(193.786)$ & $(193.165)$ \\
\hline
\end{tabular}


Table 3. (Continued.)

(1) Recent conflict b/se

\begin{tabular}{lcc}
\hline Total rainfall & -2.681 & -2.668 \\
\hline & $(3.207)$ & $(3.205)$ \\
\hline Farm daily wage (Men) & $0.021^{\star \star \star}$ & $0.021^{\star \star \star}$ \\
\hline & $(0.008)$ & $(0.008)$ \\
\hline Constant & $-1,946.915$ & $-2,298.459$ \\
\hline & $(6,844.162)$ & $(6,863.564)$ \\
\hline$R^{2}$ & 0.012 & 0.012 \\
\hline$N$ & $7,654.000$ & $7,654.000$ \\
\hline
\end{tabular}

Note: Robust standard errors in parentheses. ${ }^{\star \star \star} p<0.01,{ }^{\star \star} p<0.05,{ }^{\star} p<0.1$. For a description of the variables, see Table 1 . The following variable estimates are not shown:time fixed effect, zone fixed effect, and zone and time interaction variables. Also, the health variables are not shown (suffered from illness/injury, admitted in hospital or health facility).

hours supplied. In contrast, we find significant negative effects of both recent and longer-term violent conflict exposure on the total family hours supplied using our preferred estimation method. It is important to note that the aforementioned article focused solely on the Boko Haram conflict, while we focus on any violent conflict in Nigeria from 1997 to 2015. This could explain the differences in our findings. Also, Adelaja and George (2019a) measure conflict exposure using conflict events that we do not use. Our argument for not using conflict event counts as a measure of conflict exposure is that they may not be as effective for capturing the intensity of exposure. A conflict event in an LGA where there is violence or riots but no deaths is different in terms of impact from a conflict event in an LGA that leads to multiple fatalities. This is why we measure conflict exposure using deaths via armed conflict, and to capture the intensity, we normalized fatalities with the LGA population.

How can we interpret the results in Tables 3 and 4? For total family labor supply, our results summarized in Table 3 suggest that a 0.01 percentage point increase in recent conflict exposure leads to a decrease of approximately $20.7 \mathrm{~h}$ of the total family farm labor supply. While the accumulated impact of past conflict exposure is approximately $18.6 \mathrm{~h}$ of decrease. These are significant impacts of conflict. Moreover, some states in the north eastern part of Nigeria and the north central parts of Nigeria have experienced conflict increases far greater than this. For example, between 2012 and 2015, the mean recent conflict exposure increase in the North Eastern part of Nigeria was 0.043. This significant increase was linked primarily with the Boko Haram insurgence. If we calculate what such an increase in conflict will lead to using our FE model estimates, we find that a 0.043 percentage point increase in recent exposure suggests an approximately $88.9 \mathrm{~h}$ decline in the total family farm labor supply. A decline of such magnitude in labor supply for farm households is substantial.

Our findings suggest heterogeneity in effect across household members with significant effects solely for household heads. For household heads, the results in Table 4 suggest that a 0.01 percentage point increase in recent exposure to conflict leads to an approximate decrease of $7.3 \mathrm{~h}$ worked in the harvest season. Similarly, a 0.01 percent increase in accumulated long-term exposure to conflict leads to an approximately $7 \mathrm{~h}$ 
Table 4. The effect of violent conflict on the total hours of labor supply during the harvest season

\begin{tabular}{|c|c|c|c|c|}
\hline & \multicolumn{4}{|c|}{ (FIXED EFFECT MODEL) } \\
\hline & $\begin{array}{c}\text { (1) } \\
\text { Head b/se }\end{array}$ & $\begin{array}{c}\text { (2) } \\
\text { Spouse b/se }\end{array}$ & $\begin{array}{c}\text { (3) } \\
\text { Children b/se }\end{array}$ & $\begin{array}{c}\text { (4) } \\
\text { Relatives b/se }\end{array}$ \\
\hline Panel A & \multicolumn{4}{|c|}{ Recent conflict effect } \\
\hline \multirow{2}{*}{$\begin{array}{l}\text { Conflict recent } \\
\text { term death as } \% \\
\text { of } L G A\end{array}$} & $-726.877^{\star}$ & $-620.820^{\star}$ & -186.067 & -276.045 \\
\hline & $(384.556)$ & $(372.788)$ & $(270.542)$ & $(215.127)$ \\
\hline \multirow[t]{2}{*}{ Exposed to shock } & -134.751 & 18.030 & 28.870 & 8.753 \\
\hline & $(154.505)$ & $(23.420)$ & $(18.239)$ & $(9.715)$ \\
\hline \multirow[t]{2}{*}{ Age } & 10.923 & $26.586^{\star \star}$ & 5.917 & 0.112 \\
\hline & $(28.514)$ & $(11.730)$ & $(7.101)$ & $(2.959)$ \\
\hline \multirow[t]{2}{*}{$\mathrm{Age}^{2}$} & 0.046 & $-0.186^{\star \star}$ & -0.046 & -0.016 \\
\hline & $(0.330)$ & $(0.094)$ & $(0.058)$ & $(0.024)$ \\
\hline \multirow[t]{2}{*}{ Years of schooling } & -34.352 & -0.290 & 0.098 & 2.233 \\
\hline & $(24.455)$ & $(4.064)$ & $(2.730)$ & $(1.919)$ \\
\hline \multirow[t]{2}{*}{ Household size } & 9.678 & -21.893 & 7.138 & 3.122 \\
\hline & $(20.058)$ & $(21.910)$ & $(8.919)$ & $(4.779)$ \\
\hline \multirow{2}{*}{$\begin{array}{l}\text { Farm daily wage } \\
\text { (men) }\end{array}$} & $0.012^{\star \star \star}$ & 0.003 & 0.001 & $0.002^{*}$ \\
\hline & $(0.003)$ & $(0.003)$ & $(0.002)$ & $(0.001)$ \\
\hline \multirow[t]{2}{*}{ Constant } & $-1,507.713$ & 512.049 & $-1,980.731$ & -686.068 \\
\hline & $(4,708.136)$ & $(2,973.082)$ & $(1,287.902)$ & (711.996) \\
\hline$R^{2}$ & 0.007 & 0.005 & 0.003 & 0.008 \\
\hline$N$ & 7,654 & 7,654 & 7,654 & 7,654 \\
\hline Panel B & \multicolumn{4}{|c|}{ Long conflict effect } \\
\hline \multirow{2}{*}{$\begin{array}{l}\text { Conflict long-term } \\
\text { death as \% of } \\
\text { LGA }\end{array}$} & $-696.232^{\star}$ & -604.697 & -169.257 & $-162.858^{*}$ \\
\hline & (403.948) & (394.992) & (114.719) & (87.186) \\
\hline \multirow[t]{2}{*}{ Exposed to shock } & -134.893 & 17.918 & 28.826 & 8.614 \\
\hline & $(154.581)$ & $(23.414)$ & $(18.255)$ & $(9.759)$ \\
\hline \multirow{2}{*}{$\begin{array}{l}\text { Suffered from } \\
\text { illness or injury }\end{array}$} & -10.408 & -58.732 & -8.091 & -5.355 \\
\hline & $(52.898)$ & (39.774) & $(23.650)$ & $(11.964)$ \\
\hline $\begin{array}{l}\text { Admitted in } \\
\text { hospital or } \\
\text { health facility }\end{array}$ & 151.498 & 67.318 & -38.284 & -38.017 \\
\hline
\end{tabular}


Table 4. (Continued.)

\begin{tabular}{|c|c|c|c|c|}
\hline & \multicolumn{4}{|c|}{ (FIXED EFFECT MODEL) } \\
\hline & $\begin{array}{c}\text { (1) } \\
\text { Head b/se }\end{array}$ & $\begin{array}{c}\text { (2) } \\
\text { Spouse b/se }\end{array}$ & $\begin{array}{c}\text { (3) } \\
\text { Children b/se }\end{array}$ & $\begin{array}{c}\text { (4) } \\
\text { Relatives b/se }\end{array}$ \\
\hline & $(105.591)$ & $(70.616)$ & $(50.644)$ & $(26.901)$ \\
\hline \multirow[t]{2}{*}{ Age } & 11.420 & $27.021^{\star \star}$ & 6.035 & 0.190 \\
\hline & $(28.575)$ & $(11.812)$ & (7.111) & $(2.962)$ \\
\hline \multirow[t]{2}{*}{$\mathrm{Age}^{2}$} & 0.043 & $-0.189^{\star \star}$ & -0.047 & -0.017 \\
\hline & $(0.330)$ & $(0.095)$ & $(0.058)$ & $(0.024)$ \\
\hline \multirow[t]{2}{*}{ Years of schooling } & -34.347 & -0.287 & 0.101 & 2.250 \\
\hline & $(24.447)$ & $(4.062)$ & $(2.728)$ & $(1.921)$ \\
\hline \multirow[t]{2}{*}{ Household size } & 10.633 & -21.065 & 7.372 & 3.363 \\
\hline & $(20.018)$ & $(21.554)$ & $(8.927)$ & $(4.764)$ \\
\hline \multirow{2}{*}{$\begin{array}{l}\text { Farm daily wage } \\
\text { (men) }\end{array}$} & $0.012^{\star \star \star}$ & 0.003 & 0.001 & $0.002^{*}$ \\
\hline & $(0.003)$ & $(0.003)$ & $(0.002)$ & $(0.001)$ \\
\hline \multirow[t]{2}{*}{ Constant } & $-1,385.718$ & 616.081 & $-1,949.357$ & -638.094 \\
\hline & $(4,696.596)$ & $(2,995.034)$ & $(1,280.877)$ & (709.887) \\
\hline$R^{2}$ & 0.007 & 0.005 & 0.003 & 0.008 \\
\hline$N$ & 7,654 & 7,654 & 7,654 & 7,654 \\
\hline
\end{tabular}

se: statistics in parentheses.

${ }^{\star} p<0.05,{ }^{\star *} p<0.01,{ }^{\star * \star} p<0.001$.

Note: For a description of the variables, see Table 1 . The following variable estimates are not shown:time fixed effect, zone fixed effect, and zone and time interaction variables, distance to major road, distance to pop center, distance to market, distance to border post, distance to administrative center, annual mean temperature, annual precipitation, nutrient availability, total rainfall, and population density. Also, the health variables are not shown (suffered from illness/injury, admitted in hospital or health facility).

of decrease in labor supplied in the harvest season by the household head. These are also significant impacts of conflict. Again if we consider the mean change in conflict exposure in the north eastern zone between 2012 and 2015 and do similar calculations, a 0.043 percentage point increase in recent conflict exposure reduces farm hours by the household head by 31.3 . This decline in labor supply is also significant. ${ }^{31}$

\section{Summary and conclusion}

In this article, we examine the average impact of conflict in Nigeria on farm labor supply of agricultural households. We focus on two related questions: first, does recent exposure to violent conflict affect the total family labor hours and is there heterogeneity in effect on the number of hours worked by the household head, spouse, children, and relatives? Second, is there evidence that long-term accumulated exposure to conflict affects the total family labor hours supplied and is there heterogeneity in effect on

\footnotetext{
${ }^{31}$ If we assume a 40 -hour week, the estimated decline is nearly a week less of labor supply on average.
} 
the number of hours worked by the household head, spouse, children, and relatives? We attempt to answer these questions combining household survey panel data for Nigeria with ACLED data, exploiting a fixed effect estimation strategy.

Our results suggest that conflict negatively affects the total farm labor supply of a family. We also note heterogeneity in this effect across household members. In particular, we find that violent conflict leads to a decline in the farm labor supply of the household head, but we do not find any significant negative effects on the labor supply of children, spouse, and relatives. Simple back-of-the-envelope calculations based on our estimates suggest that the impact on farm household labor supply could be severe in magnitude in areas with sudden spikes in violent conflict, for example, the Boko Haram crises in the north eastern region of Nigeria, the farmers-herdsmen conflict in the north central region of Nigeria, and the current crises in southern Kaduna. Finding significant negative effects of conflict on total family labor supply is new, given that Adelaja and George (2019a) do not find significant effects of the Boko Haram conflict on family labor supply. While both articles use similar methodology, our analysis differs from theirs in many ways. First, we look at the effect of any recent conflict in Nigeria (focused on exposure to conflict in the last three years), while they consider only one year. In addition, we focus on the average treatment effect of any type of violent conflict, while they focus on the effect of Boko Haram. Finally, we measure exposure to conflict using fatalities normalized with population in LGA, while they focus on the count of conflict events.

Odozi and Oyelere (2019) provide evidence of the negative impact of violent conflict on income, incidence, severity, and depth of poverty in Nigeria. The results in our article provide one possible pathway for their findings. In particular, if agricultural households affected by violent conflict are forced to decrease their total labor hours worked, then assuming no substitution to other activities, their incomes will decline, and the probability of their slipping into poverty will increase.

It is important to mention one caveat when using ACLED fatality data. In particular, the collectors of the ACLED dataset are very careful in attributing any death to being linked to armed conflict. Many deaths that could have been caused by armed conflict may not have been included in the data if there was uncertainty and lack of clear information on whether the deaths were caused by armed conflict or other factors. This limitation in the reporting of deaths by armed conflict in ACLED data can create a potential downward bias in the estimated effects. Hence, the actual effect on the hours worked could be greater.

While our article provides answers to the question we focused on, there are still so many unanswered questions related to conflict in Nigeria that are relevant but we are unable to address in our article for a number of reasons, including data limitation and article scope. We hope to explore some of these questions in future work. In particular, the question whether small holder farmers are making labor substitution from agriculture to some other labor market activities or whether they are simply reducing the overall hours of labor. We hypothesize the latter based on Odozi and Uwaifo Oyelere (2019) who suggest a decline in welfare on average linked to conflict. However, concrete analysis to confirm this hypothesis is one area of potential future work. Also, exploring the pathways through which conflict affects labor supply is important. We discuss potential pathways in our article, but we are not able to identify which pathway is at work in our survey period. While we can hypothesize the more important pathways using prima facie evidence, the limitations of the LSMS data make it impossible to provide concrete answers to the exact channels or pathways. Another potential extension to our article is to test for heterogeneity in the effect of conflict on labor supply based on the type of conflict. 
Finally, it is worth noting that while the FE model mitigates biases in estimated effects, it does not deal with possible time-varying unobservables that could be correlated with our measures of conflict, and also correlated with our dependent variable. Such variables if they exist can confound estimated causal effects. We attenuate this possible source of bias by including as many time-varying controls in our regression analysis as are available in our data. Two important control groups we include are controls for idiosyncratic shocks and controls for economic, weather, and social conditions in an LGA. However, despite these aforementioned controls and others that we include, we do not claim that we completely eliminate the potential for this source of bias.

As stated at the beginning of this article, a good portion of Nigeria's labor force is employed in agriculture and it still remains the largest sector of the Nigerian economy. The agricultural sector is particularly vulnerable to violent conflict and, therefore, investigating the impact of conflict in this sector is necessary. Given the significant lingering negative effect of conflict on agricultural labor supply noted in our article, there is a need for Nigeria's leadership to do more to curb the growth of violent conflict in Nigeria. This is a social justice issue as rural vulnerable agricultural households disproportionately bear the welfare and labor supply effects of violent conflict.

Designing policies in Nigeria aimed at alleviating both the short- and longer-term micro and macro effects of reductions in labor supply in agriculture is paramount. As policy design can be challenging, partnerships between academics and policy makers aimed at creating policy alternatives and testing their effectiveness is one potential strategy the Nigerian governments may consider to facilitate effective targeted policy initiatives.

Data availability statement. Data analyzed in this study were a reanalysis of existing data, which are openly available at locations cited in the reference section of the article.

Acknowledgments. We are grateful to the editor and anonymous reviewers for their valuable comments. We also appreciate the feedback we received from conference participants at the 2020 ASSA Annual Meetings.

Funding statement. This research received no specific grant from any funding agency, commercial, or not-for-profit sectors.

Conflict of interest. None.

\section{References}

Adelaja, A., and J. George. 2019a. "Effects of Conflict on Agriculture: Evidence from the Boko Haram Insurgency." World Development 117: 184-195.

Adelaja, A., and J. George. 2019b. "Terrorism and Land Use in Agriculture: The Case of Boko Haram in Nigeria." Land Use Policy 88: 104-116.

Akresh, R., and D. de Walque. 2008. "Armed Conflict and Schooling : Evidence from the 1994 Rwandan Genocide.” Policy Research Working Paper 4606, World Bank, Washington, DC.

Bertoni, E., M. Di Maio, V. Molini, and R. Nistico. 2018. "Education is Forbidden: The Effect of the Boko Haram Conflict on Schooling in Nigeria." Working Paper 495, Centre for Studies in Economics and Finance, University of Naples, Italy.

Blattman, C., and E. Miguel. 2010. "Civil War." Journal of Economic Literature 48 (1): 3-57.

Brück, T., M. d'Errico, and R. Pietrelli. 2019. "The Effects of Violent Conflict on Household Resilience and Food Security: Evidence from the 2014 Gaza Conflict." World Development 119: 203-223.

Cameron, L., and C. Worswick. 2003. "The Labor Market as a Smoothing Device: Labor Supply Responses to Crop Loss." Review of Development Economics 7 (2): 327-341.

Courson, E. 2009. "Movement for the Emancipation of the Niger Delta (MEND) Political Marginalization, Repression and Petro-Insurgency in the Niger Delta." Working Paper 47, Nordiska Afrika Institute, Uppsala. 
Cunguara, B., A. Langyintuo, and I. Darhofer. 2011. "The Role of Non-Farm Income in Coping with the Effects of Drought in Southern Mozambique.” Agricultural Economics 42: 701-213.

Ekhator-Mobayode, U.C., and A.A. Asfaw. 2019. "The Child Health Effects of Terrorism: Evidence from the Boko Haram Insurgency in Nigeria." Applied Economics 51 (6): 624-638.

Fernández, M., A.M. Ibáñez, and X. Peña. 2014. "Adjusting the Labour Supply to Mitigate Violent Shocks: Evidence from Rural Colombia.” The Journal of Development Studies 50 (8): 1135-1155.

George, J., A. Adelaja, and D. Weatherspoon. 2020. "Armed Conflicts and Food Insecurity: Evidence from Boko Haram's Attacks.” American Journal of Agricultural Economics 102 (1): 114-131.

George, J., A. Adelaja, and D. Weatherspoon. 2020. "Armed Conflicts and Food Insecurity: Evidence from Boko Haram's Attacks.” Journal of Agricultural Economics 102(1): 114-131.

Hsiang, S.M., M. Burke, and E. Miguel. 2013. "Quantifying the Influence of Climate on Human Conflict." Science (New York, N.Y.) 341 (6151): 1235367.

Jessoe, K., D.T. Manning, and J.E. Taylor. 2018. "Climate Change and Labour Allocation in Rural Mexico: Evidence from Annual Fluctuations in Weather.” The Economic Journal 128 (608): 230-261.

Justino, P., and O.N. Shemyakina. 2012. "Remittances and Labour Supply in Post-Conflict Tajikistan." IDS Working Paper 388. Conflict, Violence and Development Research Cluster, Institute of Development Studies, UK.

Kaila, H., and M.A. Azad. 2019. "Conflict, Household Victimization, and Welfare: Does the Perpetrator Matter?” Policy Research Working Paper 9019, World Bank, Washington, DC.

Kochar, A. 1999. "Explaining Household Vulnerability to Idiosyncratic Income Shocks." American Economic Review 85 (2): 159-164.

Lamb, R. 2003. "Fertilizer Use, Risk, and Off-Farm Labor Markets in the Semi-Arid Tropics of India." American Journal of Agricultural Economics 85 (2): 359-371.

Mathengea, M.K., and D.L. Tschirley. 2015. "Off-Farm Labor Market Decisions and Agricultural Shocks among Rural Households in Kenya.” Agricultural Economics 46: 603-616.

McGuirk, E.F., and M. Burke. 2020. "The Economic Origins of Conflict in Africa." Journal of Political Economy 128 (10): 3940-3997.

McGuirk, E.F., and N. Nunn. 2020. "Nomadic Pastoralism, Climate Change, and Conflict in Africa." Working Paper 28243, National Bureau of Economic Research, USA.

Minoiu, C., and O.N. Shemyakina. 2012. "Child Health and Conflict in Cote d'Ivoire." American Economic Review: Papers and Proceedings 102 (3): 294-299.

Mitchell, H. 2019. The Effects of Conflict on Household Agricultural Investment in Nigeria. Economics Honors Projects. 90. Available at: https://digitalcommons.macalester.edu/economics_honors_projects/ 90 (accessed March 2021).

Mueller, V., and A. Quisumbing. 2010. Short- and Long-Term Effects of the 1998 Bangladesh Flood on Rural Wages. Technical Report.

Nigeria National Bureau of Statistics (NBS). 2018a. Nigeria General Household Survey (GHS), Panel 2010, Wave 1 Ref.NGA_2010_GHSP-W1_v03_M. Available at: https://microdata.worldbank.org/ (accessed 2018).

Nigeria National Bureau of Statistics (NBS). 2018b. Nigeria General Household Survey, Panel 2012-2013, Wave 2. Ref. NGA_2012_GHSP-W2_v02_M. Dataset. Available at: https://microdata.worldbank.org/ (accessed 2018).

Nigeria National Bureau of Statistics (NBS). 2018c. Nigeria General Household Survey, Panel (GHS-Panel) 2015-2016. Ref. NGA_2015_GHSP-W3_v02_M. Dataset. Available at: https://microdata.worldbank.org/ (accessed December 2018).

Nigeria National Bureau of Statistics. 2019. Nigeria General Household Survey, Panel (GHS-Panel) 2018-2019. Dataset. Available at: https://microdata.worldbank.org/ (accessed December 2019).

Nwokolo, A. 2015. "Terror and Birth Weight: Evidence from Boko Haram Attacks." Department of Economics, University of Navarra.

Odozi, J., and R.U. Oyelere. 2019. "Violent Conflict Exposure in Nigeria and Economic Welfare." Working Paper 12570. IZA Discussion Papers.

Olaniyi, R.O. 2015. "Bororo Fulani Pastoralists and Yoruba Farmers' Conflicts in the Upper Ogun River, Oyo State Nigeria, 1986-2004." Journal of Asian and African Studies 50 (2): 239-252.

Raleigh, C., A. Linke, H. Hegre, and J. Karlsen. 2010. "Introducing ACLED: An Armed Conflict Location and Event Dataset." Journal of Peace Research 47 (5): 651-660. 
Rose, E. 2001. "Ex Ante and Ex Post Labor Supply Response to Risk in a Low-Income Area." Journal of Development Economics 64 (2): 371-388.

Sidney, A.E., H. Zummo, and A.P. Kwajafa. 2017. "Effect of Boko Haram Insurgency on the Productivity of Local Farmers in Adamawa State, Nigeria." Asian Journal of Economics, Business and Accounting $\mathbf{5}$ (3): $1-7$.

Verpoorten, M. 2009. "Household Coping in War- and Peacetime: Cattle Sales in Rwanda, 1991-2001." Journal of Development Economics 88 (1): 67-86.

Verwimp, P., P. Justino, and T. Brück. 2018. "The Microeconomics of Violent Conflict.” Working Paper 280, Households in Conflict Network.

Cite this article: Odozi JC, Uwaifo Oyelere R (2021). Does violent conflict affect the labor supply of farm households? The Nigerian experience. Agricultural and Resource Economics Review 50, 401-435. https://doi.org/10.1017/age.2021.14 
Table A1. The Effect of Recent Violent Conflict on the Total Hours of Labor Supply During the Harvest Season (Heckman Model)

\begin{tabular}{|c|c|c|c|c|c|}
\hline & \multicolumn{5}{|c|}{ (HECKMAN MODEL) } \\
\hline & (1) Head b/se & (2) Spouse b/se & (3) Children b/se & (4) Relatives b/se & (5) Family b/se \\
\hline \multirow[t]{2}{*}{ Recent Conflict death as \% of LGA } & 1.021 & 0.958 & 0.523 & 1.040 & 1.023 \\
\hline & $(1.483)$ & $(1.425)$ & (24.924) & $(1.488)$ & $(1.484)$ \\
\hline \multirow[t]{2}{*}{ Exposed to Shock } & $-0.222^{\star \star \star}$ & $-0.231^{\star \star \star}$ & -0.217 & $-0.221^{\star \star \star}$ & $-0.222^{\star \star \star}$ \\
\hline & $(0.066)$ & $(0.072)$ & $(12.330)$ & $(0.066)$ & $(0.066)$ \\
\hline \multirow[t]{2}{*}{ Suffered from illness or injury } & $-0.271^{\star \star *}$ & $-0.259^{\star \star}$ & -0.260 & $-0.271^{\star \star \star}$ & $-0.271^{\star \star \star}$ \\
\hline & $(0.093)$ & $(0.102)$ & $(8.946)$ & $(0.093)$ & $(0.093)$ \\
\hline Age in completed years & $(0.015)$ & $(0.021)$ & $(6.304)$ & $(0.015)$ & $(0.015)$ \\
\hline \multirow[t]{2}{*}{ Age $^{2}$} & $-0.001^{\star \star \star}$ & $-0.001^{\star \star \star}$ & -0.001 & $-0.001^{\star \star \star}$ & $-0.001^{\star \star \star}$ \\
\hline & $(0.000)$ & $(0.000)$ & $(0.063)$ & $(0.000)$ & $(0.000)$ \\
\hline \multirow[t]{2}{*}{ Years of school } & -0.004 & $-0.018^{\star *}$ & -0.024 & -0.004 & -0.004 \\
\hline & $(0.008)$ & $(0.008)$ & $(0.982)$ & $(0.008)$ & $(0.008)$ \\
\hline
\end{tabular}




\begin{tabular}{|c|c|c|c|c|c|}
\hline Farm daily wage (men) & 0.000 & 0.000 & 0.000 & 0.000 & 0.000 \\
\hline & $(0.000)$ & $(0.000)$ & $(0.000)$ & $(0.000)$ & $(0.000)$ \\
\hline Constant & -0.223 & -0.255 & -0.273 & -0.239 & -0.223 \\
\hline \multirow[t]{2}{*}{ Panel B } & \multicolumn{5}{|c|}{ Hours Supplied Equation } \\
\hline & Head & Spouse & Children & Relatives & Family \\
\hline \multirow[t]{2}{*}{ Exposed to Shock } & -11.338 & $-43.188^{\star}$ & 12.001 & 0.643 & -0.872 \\
\hline & $(51.564)$ & $(23.465)$ & $(368.104)$ & $(8.493)$ & $(96.367)$ \\
\hline \multirow[t]{2}{*}{ Suffered from illness or injury } & -103.231 & $-94.609^{\star \star \star}$ & -68.414 & 0.039 & -197.198 \\
\hline & $(86.341)$ & (35.468) & $(266.803)$ & (12.549) & (121.596) \\
\hline Age in completed years & $(12.231)$ & $(7.467)$ & (.) & $(1.472)$ & $(15.891)$ \\
\hline \multirow[t]{2}{*}{ age $^{2}$} & 0.061 & -0.087 & -0.121 & -0.018 & -0.090 \\
\hline & $(0.137)$ & $(0.075)$ & $(1.401)$ & $(0.014)$ & $(0.169)$ \\
\hline \multirow[t]{2}{*}{ Years of school } & $-17.080^{\star \star}$ & 1.838 & -3.271 & -1.200 & $-25.736^{\star \star}$ \\
\hline & $(7.709)$ & $(2.898)$ & $(154.676)$ & $(0.738)$ & $(11.106)$ \\
\hline \multirow[t]{2}{*}{ Farm daily wage (men) } & $0.011^{\star \star \star}$ & $0.004^{\star}$ & 0.000 & 0.002 & $0.015^{\star \star}$ \\
\hline & $(0.003)$ & $(0.002)$ & $(0.006)$ & $(0.001)$ & $(0.007)$ \\
\hline
\end{tabular}


Table A1. (Continued.)

\begin{tabular}{|c|c|c|c|c|c|}
\hline & \multicolumn{5}{|c|}{ (HECKMAN MODEL) } \\
\hline & (1) Head b/se & (2) Spouse b/se & (3) Children b/se & (4) Relatives b/se & (5) Family b/se \\
\hline Constant & $(1,336.212)$ & $(621.212)$ & $(7,366.368)$ & (217.415) & (1943.199) \\
\hline$\rho$ & -0.003 & 2.072 & 1.842 & $-0.021^{\star}$ & -0.005 \\
\hline N & 7,631 & 7,631 & 7,631 & 7,631 & 7,631 \\
\hline
\end{tabular}

se: Robust standard errors in parentheses.

${ }^{\star} p<0.05,{ }^{\star \star} p<0.01,{ }^{\star \star \star} p<0.001$.

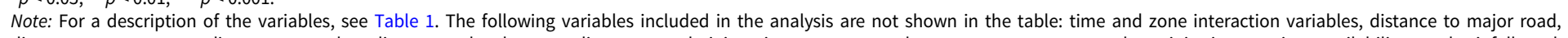
distance to pop center, distance to market, distance to border post, distance to administrative center, annual mean temperature,annual precipitation, nutrient availability, total rainfall, and population density. NC: non convergence. 
Table A2. The Effect of Long Violent Conflict on the Total Hours of Labor Supply During the Harvest Season (Heckman Model)

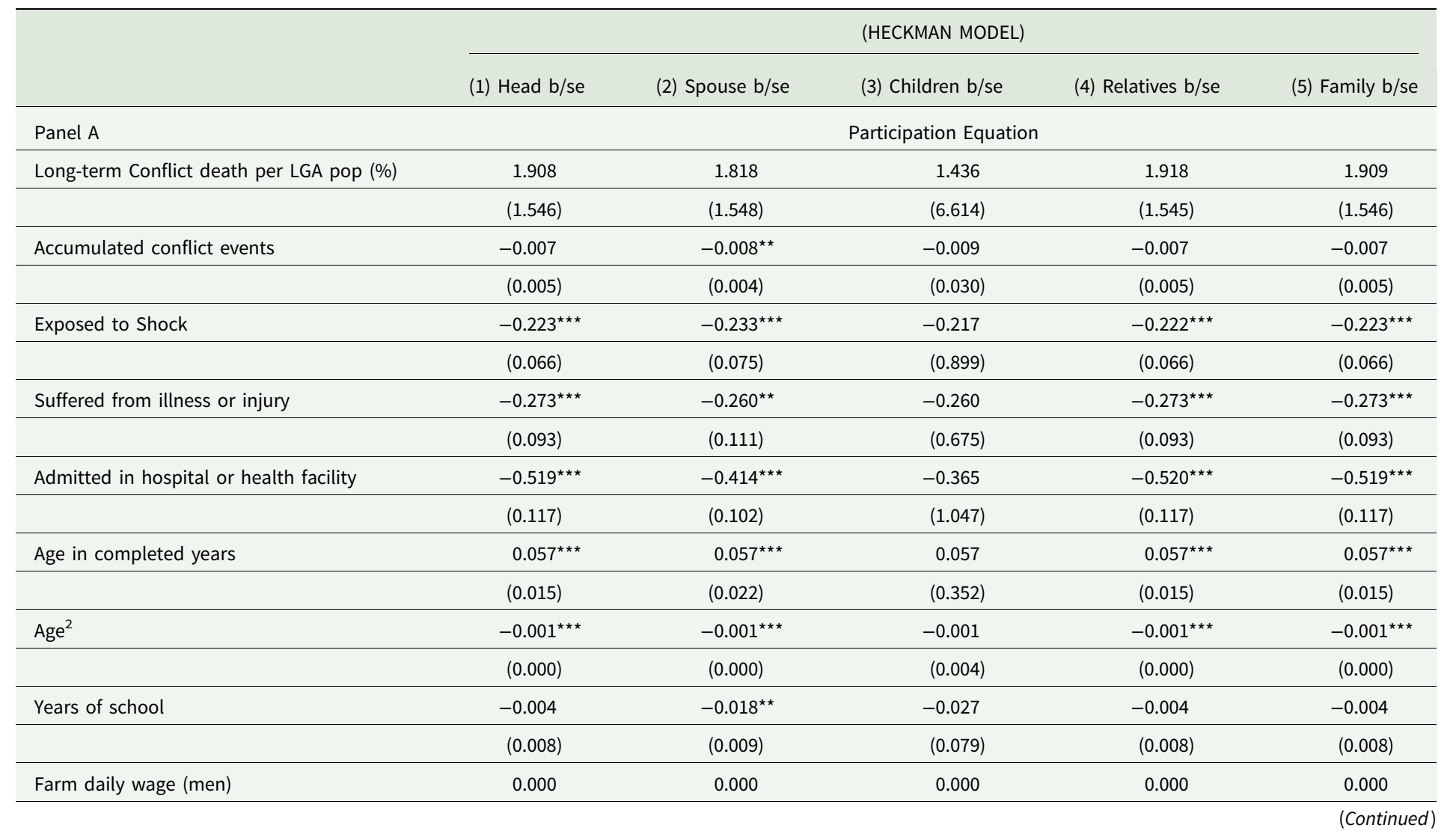


Table A2. (Continued.)

\begin{tabular}{|c|c|c|c|c|c|}
\hline & \multicolumn{5}{|c|}{ (HECKMAN MODEL) } \\
\hline & (1) Head b/se & (2) Spouse b/se & (3) Children b/se & (4) Relatives b/se & (5) Family b/se \\
\hline & $(0.000)$ & $(0.000)$ & $(0.000)$ & $(0.000)$ & $(0.000)$ \\
\hline \multirow[t]{2}{*}{ Constant } & 0.008 & -0.022 & -0.044 & -0.005 & 0.008 \\
\hline & $(1.714)$ & $(2.259)$ & $(2.964)$ & $(1.714)$ & $(1.714)$ \\
\hline \multirow[t]{2}{*}{ Panel B } & \multicolumn{5}{|c|}{ Hours Supplied Equation } \\
\hline & Head & Spouse & Children & Relatives & Family \\
\hline \multirow[t]{2}{*}{ Long-term Conflict death per LGA pop (\%) } & $-707.680^{\star \star}$ & -238.730 & -271.696 & -8.306 & $-1,351.018^{\star \star}$ \\
\hline & $(299.675)$ & $(230.760)$ & $(282.775)$ & $(74.769)$ & $(659.778)$ \\
\hline \multirow[t]{2}{*}{ Exposed to Shock } & -11.005 & $-42.647^{\star}$ & 11.130 & 0.892 & 1.658 \\
\hline & $(51.675)$ & $(23.535)$ & $(48.124)$ & $(8.500)$ & (97.204) \\
\hline \multirow[t]{2}{*}{ Suffered from illness or injury } & -104.662 & $-96.752^{\star \star \star}$ & -72.701 & -0.053 & $-200.566^{\star}$ \\
\hline & $(86.222)$ & $(35.765)$ & $(49.966)$ & $(12.526)$ & $(121.848)$ \\
\hline \multirow[t]{2}{*}{ Admitted in hospital or health facility } & 112.461 & -49.718 & $-218.177^{\star}$ & 15.649 & 208.983 \\
\hline & $(116.630)$ & $(62.449)$ & $(116.610)$ & $(22.469)$ & (180.053) \\
\hline \multirow[t]{2}{*}{ Age in completed years } & -5.604 & 9.796 & 10.543 & $2.962^{\star \star}$ & 15.760 \\
\hline & $(12.276)$ & $(7.560)$ & $(111.722)$ & $(1.475)$ & $(15.944)$ \\
\hline \multirow[t]{2}{*}{$\mathrm{Age}^{2}$} & 0.059 & -0.087 & -0.123 & -0.017 & -0.092 \\
\hline & $(0.137)$ & $(0.075)$ & (1.103) & $(0.014)$ & $(0.170)$ \\
\hline \multirow[t]{2}{*}{ Years of school } & $-17.147^{\star \star}$ & 1.930 & -2.641 & -1.189 & $-25.769^{\star \star}$ \\
\hline & (7.695) & $(2.929)$ & (11.855) & $(0.735)$ & (11.086) \\
\hline
\end{tabular}




\begin{tabular}{|c|c|c|c|c|c|}
\hline Farm daily wage (men) & $0.011^{\star \star \star}$ & $0.004^{\star}$ & 0.001 & 0.002 & $0.015^{\star \star}$ \\
\hline & $(0.003)$ & $(0.002)$ & $(0.002)$ & $(0.001)$ & $(0.007)$ \\
\hline \multirow[t]{2}{*}{ Constant } & $2,026.219$ & -735.198 & $-1,175.770$ & $-395.449^{\star}$ & -190.856 \\
\hline & $(1,344.571)$ & $(652.154)$ & $(2,381.445)$ & $(217.471)$ & $(1960.295)$ \\
\hline \multirow[t]{2}{*}{$\rho$} & -0.003 & 2.158 & 1.886 & $-0.022^{\star}$ & -0.005 \\
\hline & $(0.004)$ & NC & $(5.542)$ & $(0.011)$ & $(0.008)$ \\
\hline$c h i^{2}$ & 868.777 & 776.813 & 366.830 & 316.402 & 898.417 \\
\hline$N$ & 7,631 & 7,631 & 7,631 & 7,631 & 7,631 \\
\hline
\end{tabular}

se: Robust standard errors in parentheses.

${ }^{*} p<0.05,{ }^{* \star} p<0.01,{ }^{* * *} p<0.001$.

Note: For a description of the variables, see Table I. The following variables included in the analysis are not shown in the table: time and zone interaction variables, distance to major road, distance to pop center, distance to market, distance to border post, distance to administrative center, annual mean temperature, annual precipitation, nutrient availability, total rainfall, and population density. NC: Non convergence. 